\title{
A transnacionalização de objetos escolares no fim do século XIX
}

\begin{abstract}
Wiara Alcântara ${ }^{1}$
RESUMO: Este artigo propõe reflexão sobre a transnacionalização ${ }^{2}$ de objetos escolares no fim do século XIX, dando especial atenção às carteiras. Nesse período de estruturação da escola moderna, pública e obrigatória em muitos países do Ocidente, observa-se uma circulação internacional de discursos e saberes sobre o corpo infantil, o corpo do cidadão escolarizado, no âmbito da higiene pública e escolar. Ao lado das questões pedagógicas, médicas e higiênicas, a industrialização, as inovações tecnológicas e a globalização propiciam a fabricação e a difusão de um novo objeto que se tornaria cada vez mais imprescindível ao funcionamento das instituições de ensino, a carteira escolar. A partir da análise dos catálogos das indústrias de mobiliário escolar, discorro sobre os modelos de carteira mais hegemônicos, expostos nas exposições universais do século XIX. Destaco as empresas norte-americanas e francesas que disputavam a liderança do mercado de mobiliário escolar, num contexto em que a escola emerge como um importante mercado consumidor. Por meio do relatório do jury da Exposição Pedagógica de 1883, no Rio de Janeiro, é possível perquirir as características técnicas e higiênicas que, no Brasil, estavam sendo apreciadas na fabricação das carteiras. Como resultado, evidencia-se a via de mão dupla da relação entre escola, indústria e Exposições Universais. De um lado, a escola movimenta o mercado. De outro lado, o Estado depende do mercado para produção, em grande quantidade e em curto tempo, de um mobiliário padronizado que corrobore a expansão do ensino.
\end{abstract}

PALAVRAS-CHAVE: Transnacionalização. Carteira escolar. Exposições Universais. Exposições pedagógicas. Patentes.

ABSTRACT: This article aims at reflecting about the school objects transnationalization ${ }^{3}$ at the end of the nineteenth century, focusing on the chairs. During this structure period of the modern, public and mandatory school, in many western countries, it was seen an international circulation of speeches and knowledgmentes about the children's body, the school citizen body, in the Public Hygiene and School field. Besides the pedagogical, medical and hygienic issues, the
1. Doutora em educação pela Faculade de Educação da USP, membro do Núcleo Interdisciplinar de Estudos e Pesquisas em História da Educação (NIEPHE-USP). Email: <wiaraped@yahoo.com.br>.

2. Ver Barnita Bagchi; Eckhardt Fuchs; Kate Rousmaniere (2014).

3. Ver Barnita Bagchi; Eckhardt Fuchs; Kate Rousmaniere (2014). 
4. Cf. Ulpiano Meneses (1998, p. 90).

5. Cf. Ulpiano Meneses (1998, p. 92).

6. Ver Ulpiano Meneses (1998).

7. Cf. Ulpiano Meneses (1998, p. 95). industrialization, the technological inventions and the globalization, propitiate the manufacturation and the difusion of a new object that would be much more necessary to the functioning of the teaching institutions, the school desk. Through the school furniture industries' catalogues, I argue about the desk more hegemonic patterns, exposed at the twentieth century Universal Expositions. I highlight the American and French factories which disputed the leadership of the school furniture market, inside a context in which the school emerges as an important consumer market. Through the Jury Report of the Pedagogical Exposition in 1883, in Rio de Janeiro, it is possible to notice the technical and hygienic features that, in Brazil, were taken into account when the desks were made. As a result, it is evident the two way street relation among school, industry and the Universal Expositions. On the one hand, the school rotates the market. On the other hand, the State depends on the market for production, in a high quantity and in a short period of time, of a standard furniture which improves the teaching expansion.

KEYWORDS: Transnationalization. School Desk. Universal Expositions. Pedagogical Expositions. Patents.

Introdução

A proposta de investigar os objetos escolares, mais especificamente as carteiras, a partir de uma perspectiva transnacional fundamenta-se na recusa de tomar o primado geográfico de definição das fronteiras nacionais para compreender a constituição e expansão da escola pública e obrigatória, na passagem do século XIX ao XX. Com a história transnacional, fica em evidência a rede complexa de relações na qual a escola e seus materiais encontram-se imersos.

problema aqui levantado será analisado atentando para os aportes da cultura material. Nesse âmbito, Ulpiano Menezes levanta questões teóricometodológicas que são instigadoras quando se lança mão de artefatos materiais como documento:

qual a natureza do objeto material como documento, em que reside sua capacidade documental, como pode ele ser suporte da informação? [...] que tipo de informação podem os artefatos conter, especialmente de conteúdo histórico? ${ }^{4}$

Para o autor, os traços materialmente inscritos nos artefatos orientam leituras que permitem inferências, pois a matéria-prima, as técnicas de fabricação, a morfologia do artefato, os sinais de uso, os indícios de diversas durações, selam no objeto informações materialmente observáveis sobre a natureza e as propriedades dos materiais, bem como da organização econômica, social e simbólica da existência social e histórica do objeto.

Nesse caso, os "objetos materiais têm uma trajetória, uma biografia" que é preciso considerar; não para recompor o cenário material, mas para entender os artefatos na interação socialo. Portanto, são fontes "excepcionais para se entender a sociedade que os produziu ou reproduziu enquanto, precisamente objetos históricos" $"$. 
Investigar a biografia dos objetos é um procedimento fértil que pode ser usado para perceber como em torno, neste caso, da carteira escolar foram instituídos discursos médicos, higiênicos, pedagógicos, econômicos, tecnológicos e comerciais. $\bigcirc$ destaque aqui será dado a estes três últimos aspectos.

Além da abordagem da cultural material, a categoria transnacionalização será central na análise. Bagchi, Fuchs e Rousmaniere ${ }^{8}$ falam em uma virada transnacional e defendem a recontextualização da noção de espaço e redefinição de fronteiras territoriais. Para eles, os processos de glo-balização requerem novas pesquisas que vão além das narrativas históricas tradicionais baseadas no Estado-nação.

Fuchs salienta que o espaço não pode ser visto como uma categoria objetiva, mas como "uma forma de representação e interpretação espacial coletiva do grupo social e da comunidade" ". Segundo ele, o conceito de história transnacional, como história para além das fronteiras, refere-se a três aspectos: a) centra-se não em espaços nacionais, mas em espaços que são mutáveis; b) considera os contextos das dependências, relações e envolvimentos transnacionais; c) examina o desenvolvimento da nação como um fenômeno global.

Quanto às fontes, lancei mão de catálogos das indústrias de mobiliário escolar e dos relatórios do júri da Exposição Pedagógica de 1883, no Rio de Janeiro. Os catálogos dos materiais exibidos nas exposições universais eram enviados às escolas que poderiam fazer seus pedidos às empresas. Os relatórios do júri consistem em um documento elaborado por especialistas, no qual descrevem os objetos que concorreram a prêmios, bem como os motivos das premiações recebidas na exposição. Tais relatórios indiciam a apreciação e a apropriação dos modelos de carteira disponíveis no mercado pelos educadores brasileiros.

No fim do século XIX, fica em evidência a natureza tripla da modernidade, apontada por Schriewer ${ }^{10}$ : a) a transmissão de uma ideologia da educação e do desenvolvimento particularmente moderna; b) a aceitação global de modelos racionais de escolarização pública, conduzida pelo Estado; c) e, finalmente, o processo mundial de uma expansão educacional pela escolaridade obrigatória.

Essa modernidade se expressa nos objetos escolares, adquiridos pelos Estados para promover a expansão educacional e a escolaridade obrigatória. Para propagação dos objetos escolares, as exposições universais contribuíram decisivamente.

Heloisa Barbuy ${ }^{11}$ defende que tanto os museus, quanto às exposições podem ser mais bem compreendidos quando vistos em seu desenvolvimento histórico, desde os gabinetes de curiosidades, a partir do século XVI, até atingir a conformação com que se disseminam no século XIX. Visto na perspectiva da cultura material e do contexto da sociedade industrial, o século XIX é período de mudanças culturais expressivas, especialmente ligadas à visualidade, para cujo entendimento análises sobre museus e exposições são estratégicas ${ }^{12}$.
8. Ver Barnita Bagchi; Eckhardt Fuchs; Kate Rousmaniere (2014).

9. Cf. Eckhardt Fuchs (2014, p. 11). Todas as traduções são da autora.

10. Ver Jürgen Schriewer (2004).

11. Anotações de aula da disciplina História cultural do museu moderno, dos gabinetes de curiosidades ao século XIX, ministrada pela profa. Dra. Heloisa Barbuy, no primeiro semestre de 2010, na Faculdade de Filosofia, Ciências e Letras e no Museu Paulista.

12. Ver Heloisa Barbuy (1999). 
13. Ver Mauricio Tenório Trillo (1988)

Nas exposições, um conjunto de material e mobiliário escolar, dentre eles, as carteiras escolares, aparecem em abundância como exemplos do progresso científico, técnico e material no campo da educação. Nesse momento, os modelos ali apresentados são aqueles que deveriam figurar nas escolas e países que pretendessem estar em dia com o progresso, também no campo da instrução.

Quanto à ideia de progresso, vale destacar a obra Artilugio de la Nación Moderna: México en las exposiciones universales (1880-1930), de Mauricio Tenório Trillo $^{13}$. Ainda que seja examinada a presença do México nas exposições universais com o objetivo de avaliar como tal participação sinaliza o conceito em formação de uma nação moderna, e ainda que não trate do caso específico do Brasil, a obra é representativa ao mostrar o impulso dos países em direção à modernidade. Essa corrida é evidenciada pelo autor quando ele expõe características da segunda metade do século XIX e início do XX que atravessam também as exposições: a) a liberdade (veneração do livre comércio); b) o progresso (fundamentado na ciência e na indústria); c) o nacionalismo (ostentação de uma pretensa superioridade racial e cultural, o nacionalismo se tornou um requisito quase ontológico da modernidade).

Pensar o mobiliário escolar nas exposições ajuda a entender a escolaridade obrigatória, a partir da cultura material, da história transnacional e econômica da escola, e, ilumina aspectos relevantes da constituição da escola pública. O final do século XIX e as exposições desse período (importante expressão da sociedade industrial) traziam uma ordem transnacional articulada pelo comércio, pela tecnologia e pela mercadoria.

Por isso, é importante indagar: quais empresas comercializavam carteiras escolares no período em estudo? Que tecnologias e materiais empregavam em suas mercadorias? Que argumentos eram usados pelos industriais para conquistar os diferentes Estados e suas respectivas escolas como mercado consumidor? Como o Brasil participa desse processo de modernização do mobiliário escolar?

Para abordar tais questões, o texto está dividido em três partes. Na primeira, destaco os modelos de carteira apresentados nas exposiç̃ẽes universais do fim do século XIX. Cada empresa exibia aqueles que considerava mais modernos, com emprego de novas técnicas e tecnologias, cujo design atendia aos padrões ergonômicos ditados pela Medicina, pela Pedagogia e pela Higiene. Na segunda parte, de outro modo, também coloco em evidência as disputas das empresas no mercado de mobiliário escolar por meio da problematização das patentes de propriedade industrial. Na terceira parte, analiso o relatório do júri da Exposição Pedagógica de 1883, no Rio de Janeiro, demonstrando como o Brasil se insere no processo da modernização da escola e seus objetos, no período em estudo.

A carteira escolar nas exposições universais do século XIX

No âmbito da cultura material e da história transnacional é importante destacar o lugar das exposições, sejam as universais ou as pedagógicas. Segundo 
Moysés Kuhlmann Júnior14, a "educação esteve presente em todos [os eventos] desde 1862, em Londres, quando ganhou espaço para figurar ao lado da exibição da produção industrial e artística e da demonstração de novidades tecnológicas". Nelas, a educação foi prestigiada como "signo de modernidade" e como "um dos pilares centrais para a normatização e edificação controlada da sociedade ocidental moderna"15.

As exposições universais do século XIX foram o lugar, por excelência, onde as nações apresentaram ao mundo seus progressos nas mais diversas áreas. $\mathrm{Na}$ área educacional não era diferente. Elas se constituíram em espaço privilegiado de divulgação e propaganda de novos objetos, cujos fabricantes tinham como alvo a escola.

A primeira exposição universal ocorreu em Londres no ano de 1851. No entanto, de acordo com Moysés Kuhlmann Júnior, foi na terceira exposição, a de 1862, também em Londres, que a educação "ganhou espaço para figurar ao lado da exibição da produção industrial e artística e da demonstração de novidades tecnológicas" 16 . Mas, como um subtema da educação, quando o mobiliário escolar passaria a ter destaque? Quem eram os expositores de destaque? Quais os modelos de carteira e suas respectivas propostas?

Peyranne ${ }^{17}$ aponta a relevância de duas exposições para a questão do mobiliário escolar: a de 1867, em Paris; e a de 1873, em Viena. O Brasil participou das duas, sendo que o tema da última foi "cultura e educação"18. Atuação de destaque nos grupos sobre educação teve Ferdinand Buisson, diretor do ensino primário francês. Em seu Dictionnaire de Pédagogie et d'instruction primaire, no verbete "Mobiliário Escolar"19, o autor salienta que há muito tempo se reconhece na França a necessidade de estabelecer um mobiliário escolar em condições que as crianças possam ler e escrever, preservando-os de atitudes viciosas. Segundo Buisson ${ }^{20}$,

Quase todos os móveis são inadequados e em estado deplorável. Há apenas uma cadeira para o professor, alguma mesa ruim sem encosto, nem tinteiros e bancos e bancos ao longo das paredes para as crianças que não podem ter mesas. Vemos escolas suntuosas com um mobiliário miserável. As carteiras são disjuntas, ou muito altas para os pequenos ou muito baixas para os grandes.

Para o inspetor geral do ensino primário, a questão não foi realmente posta na França até a Exposição Universal de 1867. Isso porque em outros países, como nos Estados Unidos,

em 1854, a obra de Henry Barnard tinha chamado a atenção para a importância da boa mobília escolar; na Alemanha, por volta de 1858, o Dr. Schreber; finalmente, de 1863 a 1865, o Dr. Fahrner para Zurique e o Dr. Guillaume em Neuchâtel, fizeram uma reforma nas carteiras indicando os danos à saúde dos alunos ${ }^{21}$.

Ainda segundo Peyranne, depois desse período, "toda uma cultura nasce em torno da carteira". Na exposição de 1867, "uma sala é reservada ao
14. Cf. Moysés Kuhlmann Júnior (2001, p. 9).

15. Cf. Moysés Kuhlmann Júnior (2001, p. 9).

16. Cf. Moysés Kuhlmann Júnior (2001, p. 9).

17. Ver Josette Peyranne (2001).

18. A participação do Brasil é mencionada por Brigitte Schoroeder-Gudehus; Anne. Rasmussen em Les Fastes Du Progrès: Guide Dês Expositions Universaelles, 1851-1992. Ver Brigitte Schoroeder-Gudehus; Anne. Rasmussen (1992, p. 78, 86).

19. Cf. Ferdinand Buisson (1888, p. 1940-1949).

20. Cf. Ferdinand Buisson (1888, p. 1941).

21. Cf. Ferdinand Buisson (1888, p. 1941). 
22. Cf. Josette Peyranne (2001, p. 132).

23. Charles-Jacques Defodan foi um "pedagogo francês, nascido em Rouen 14 de maio de 1832, foi professor na Escola Normal de formação de professores de Auteuil (1872-1879), bibliotecário do Musée pédagogique (1879-1885); inspector primário em Paris (18851891); membro da maioria das comissões de educação primária", cf. http://www. inrp.fr/edition-electronique/lodel/dictionnaire-ferdinand-buisson/document. php?id=2523. Acesso em: 19 ago. 2013.

24. Cf. Josette Peyranne (2001, p. 132).

25. Ver Josette Peyranne (2001). espaço escolar. Modelos de carteira inteiramente novos são apresentados"22. Na ocasião, "a grande superioridade dos modelos americanos é reconhecida". Tomando como fonte o relato de visita feito por C. Defodon ${ }^{23}$, para quem os modelos mais marcantes provieram da América, Peyranne afirma que o destaque foi a mesa-banco americana de lllinois (figura 1).

modelo americano apresentado em Paris é de um lugar, descrevemos um banco sólido e confortável, cada carteira é fixada sobre um sólido suporte de ferro [...] uma das novidades é no banco, ele se eleva de maneira a deixar cada criança tomar seu lugar mais facilmente. Os suportes, munidos de um sistema de cremalheira, permitem ajustar a altura da mesa ao tamanho das crianças. É a primeira carteira de altura variável24.

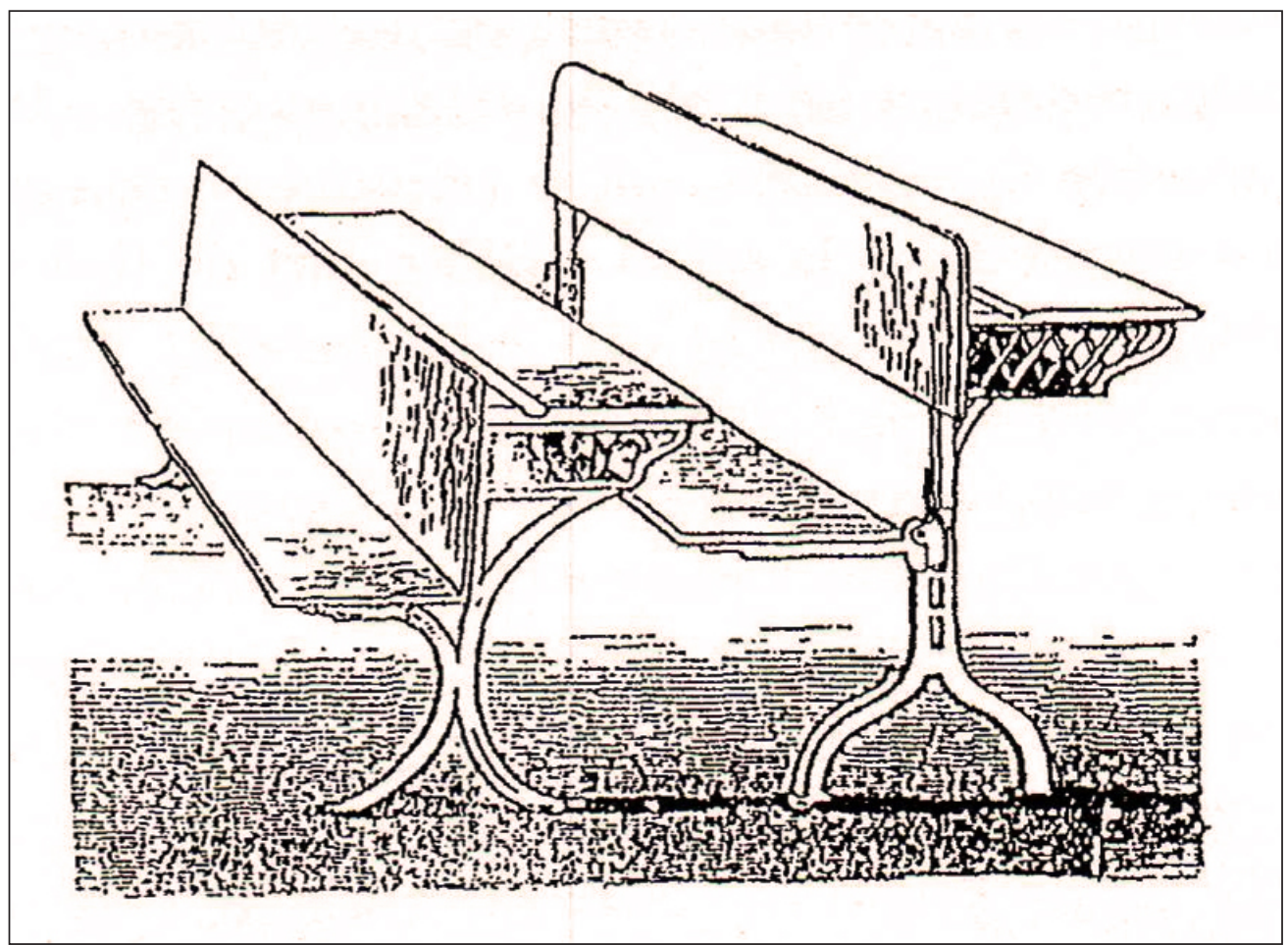

Figura 1 - Mesa-banco americano (Illinois), 1867. Imagem extraída do livro de Aimé Riant (1874, p. 124).

Outro modelo destacado foi o norveguês, pois diante da mesa, um triângulo se eleva e serve de porta livros. Porém, foi considerado inadaptável na França devido ao alto custo de sua fabricação (figura 2).

A Inglaterra apresentou o modelo Windsor, considerado funcional uma mesa de quatro lugares com um longo banco que faz corpo com a mesa no meio de um pé de ferro (figura 3).

Peyranne ${ }^{25}$ (200 1 ) situa aí o nascimento de um novo comércio, quando os modelos americanos são comprados, depois do fim da exposição, pela empresa francesa Hachette et Cie. Os antigos bancos sem encosto e as longas mesas de 
madeira, que compunham o mobiliário de muitas escolas até então, passam a ser, em comparação com o mobiliário moderno das exposições, considerados impróprios à saúde física dos alunos e à organização do trabalho escolar. "A precariedade do espaço e do mobiliário escolar torna-se uma preocupação das mais importantes no meio educacional [...] o antigo mobiliário será definitivamente repudiado em 1880 pelo regulamento de July Ferry"26.

Se, em 1867, nenhuma observação foi feita sobre o mobiliário francês, em 1873, na Exposição Universal de Viena, "A França participa ativamente e apresenta suas novas carteiras" 27 . Em duas salas de exposição da seção francesa havia 47 espécies de bancos.

Se, em 1867, há o nascimento do comércio internacional do mobiliário escolar com o predomínio americano, em 1873, há o nascimento da concorrência não só quanto às propostas e aos conceitos de carteira escolar, mas também de mercado consumidor.

Ferdinand Buisson ${ }^{28}$ associa a "rivalidade que se exprime no domínio do mobiliário escolar" à expressiva participação da França, nesse domínio, a partir de então.

Numerosos países participaram desta exposição, a carteira se diversificou, ela pode ser fixa ou com tabuleta móvel, o assento ou ambos. A invenção e originalidade são homenageadas; cada um apresentou seu mobiliário e argumentou as vantagens de sua própria criação. A França, na escolha dos modelos expostos, afirma uma certa experiência neste domínio 29 .

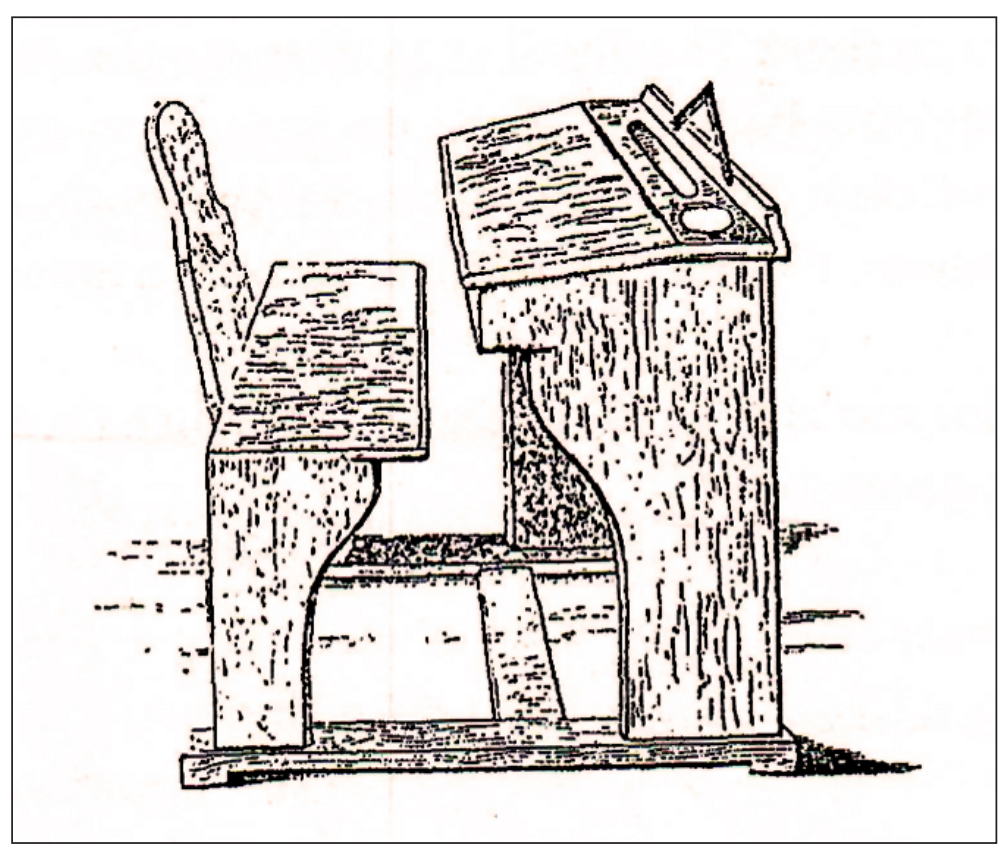

26. Cf. Josette Peyranne (2001, p. 135).

27. Cf. Josette Peyranne (2001, p. 135).

28. Cf. Ferdinand Buisson (1875, p. 91).

29. Cf. Josette Peyranne (2001, p. 135).
Figura 2 - Carteira e banco norueguês, de aluno em uma escola sueca, 1867. Imagem extraída do livro de Aimé Riant (1874, p. 1321. 
30. Imagem da carteira Bapterosses pode ser vista no ponto 3 deste artigo.

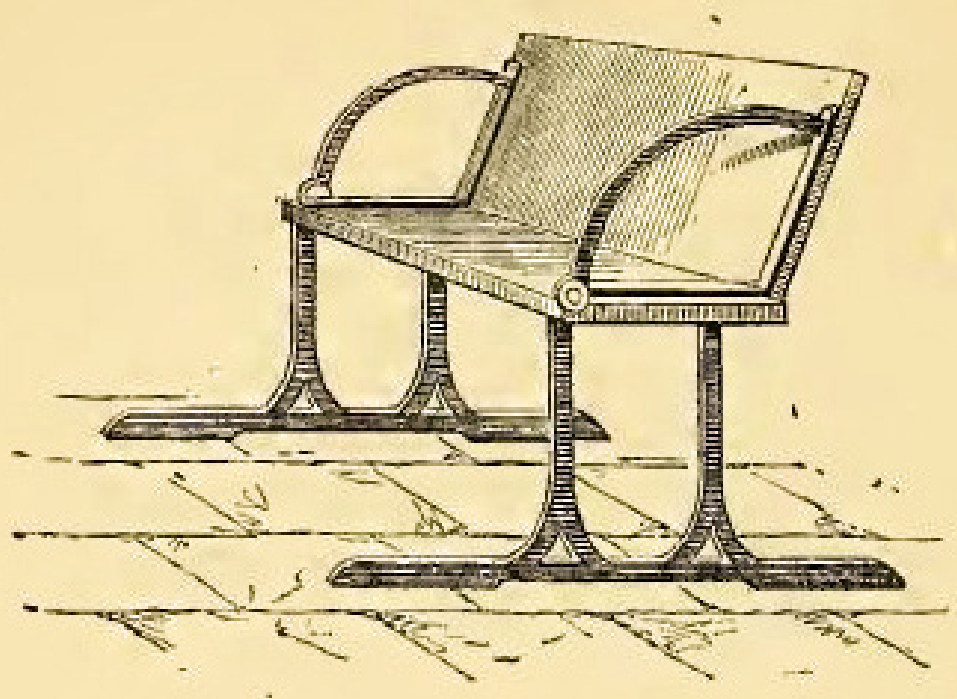

Figura 3 - Carteira Windsor, 1867. Imagem extraída do livro de Aimé Riant (1874, p. 128).

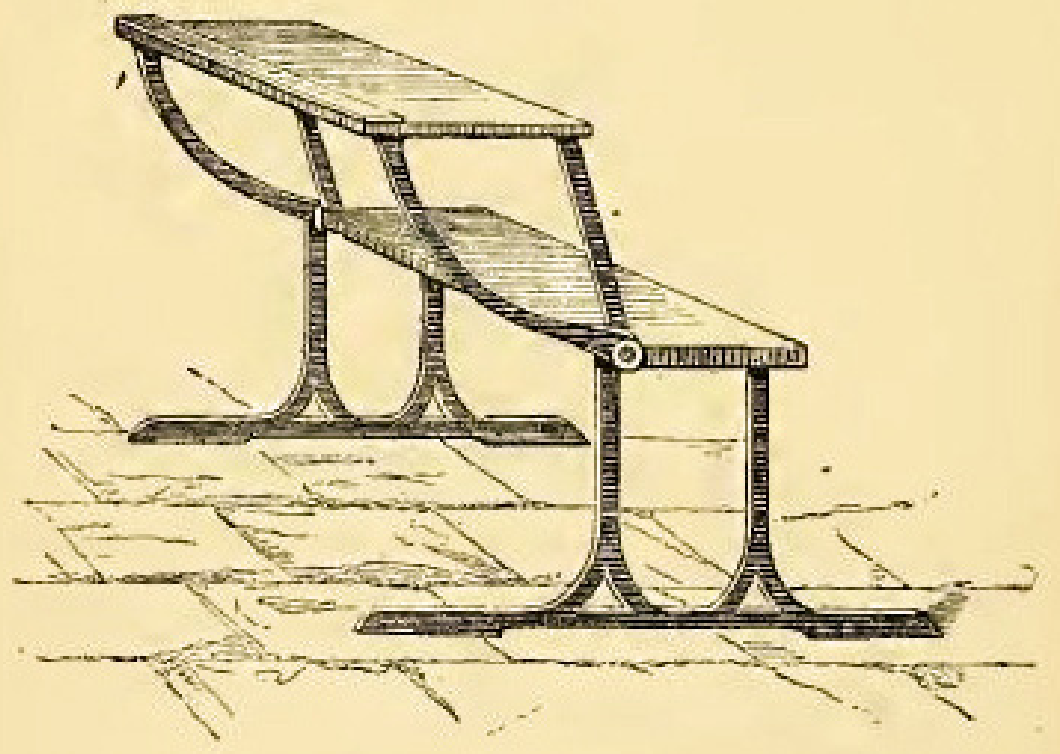

Peyranne apresenta quatro modelos postos à venda ou testados nas escolas francesas: primeiro, o novo modelo das escolas de Paris, concebido por $\bigcirc$. Gréard, um mobiliário fixo, com três lugares, possuindo os assentos isolados (figura 4).

modelo mais elogiado da Exposição Universal de 1873 foi o Bapterosses ${ }^{30}$, premiado com diploma de mérito. $\bigcirc$ diploma de mérito, de acordo 
com Schoroeder-Gudehus e Rasmussen31, "era semelhante às menções honrosas premiadas às exposições precedentes, recompensa certos produtos cujos méritos não são suficientes para obtenção de medalhas".

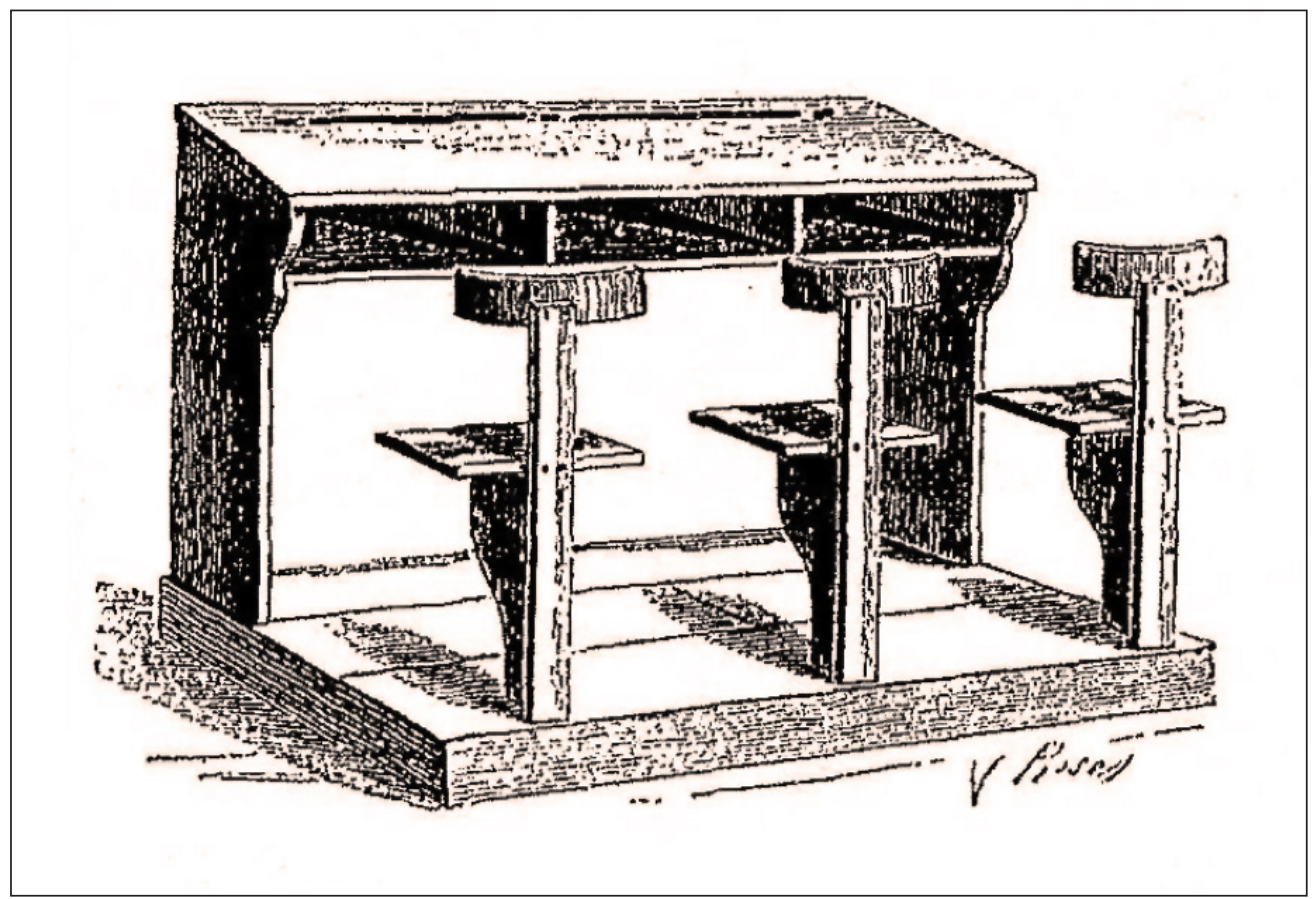

Figura 4 - Novo modelo das escolas de Paris. Imagem extraída do livro de Aimé Riant (1874, p. 164).

Pela França, Cardot expôs dois modelos. Uma carteira em teste na direção de ensino rimário de Paris e um móvel que servia de carteira e banco (figuras 5 e 6).

$\bigcirc$ mesmo móvel possuía duas funções: banco e carteira. " $\bigcirc$ banco, em posição abaixada serve de assento às crianças durante a recreação; em posição levantada, serve de mesa para o almoço dos escolares"32. As duas placas de madeiras eram ligadas por uma dobradiça que permitia a articulação do encosto.

Apesar de serem consideradas uma novidade, essas carteiras "apresentam semelhanças com a carteira Windsor exibida em Paris em 1867"33. Além dos modelos franceses, Peyranne apresenta os modelos mais representativos de outros países. Os vindos dos Estados Unidos "[...] adquiriram, à época, uma reputação inigualável pela elegância e solidez" 34 .

A carteira Andrew, de Chicago, possuía uma base de ferro. "A mesa é integrada com o banco do aluno sentado à frente dele. Ela é munida de um tinteiro e uma gaveta fechada por uma grade" (figura 7$)^{35}$.

Observa-se que o modelo do sistema Stevens é semelhante ao do sistema Andrew. Segundo a mesma autora, os americanos ganharam duas distinções: o diploma de mérito concedido ao mobiliário da escola superior e da escola normal de Boston; e uma medalha de mérito atribuída a Joseph Ross, de
31. Cf. Brigitte Schoroeder-Gudehus; Anne Rasmussen (1992, p. 88).

32. Cf. Josette Peyranne (2001, p. 137).

33. Cf. Josette Peyranne (2001, p. 137).

34. Cf. Josette Peyranne (2001, p. 138).

35. Cf. Josette Peyranne (2001, p. 138). 

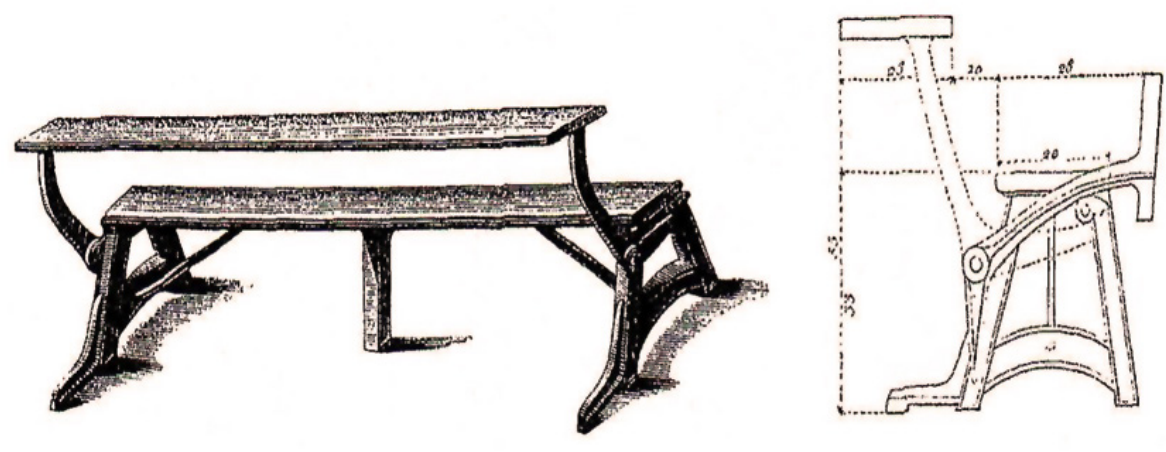

Figura 5 - Sistema Cardot - mobiliário de pátio com encosto móvel. Imagem extraída do livro de Josette Peyranne (2001, p. 137).

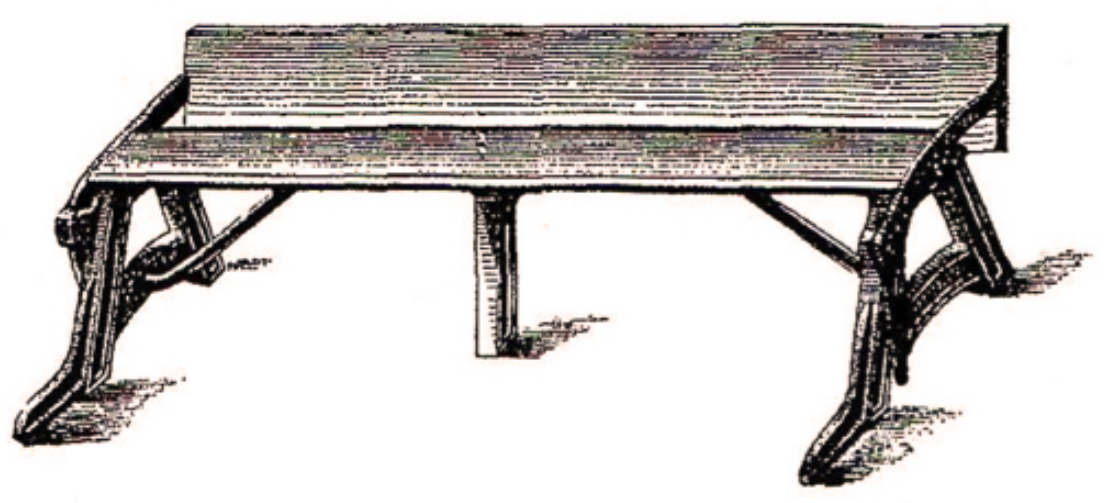

Figura 6 - Sistema Cardot-banco em posição abaixada. Imagem extraída do livro de Josette Peyranne (2001, p. 1381.
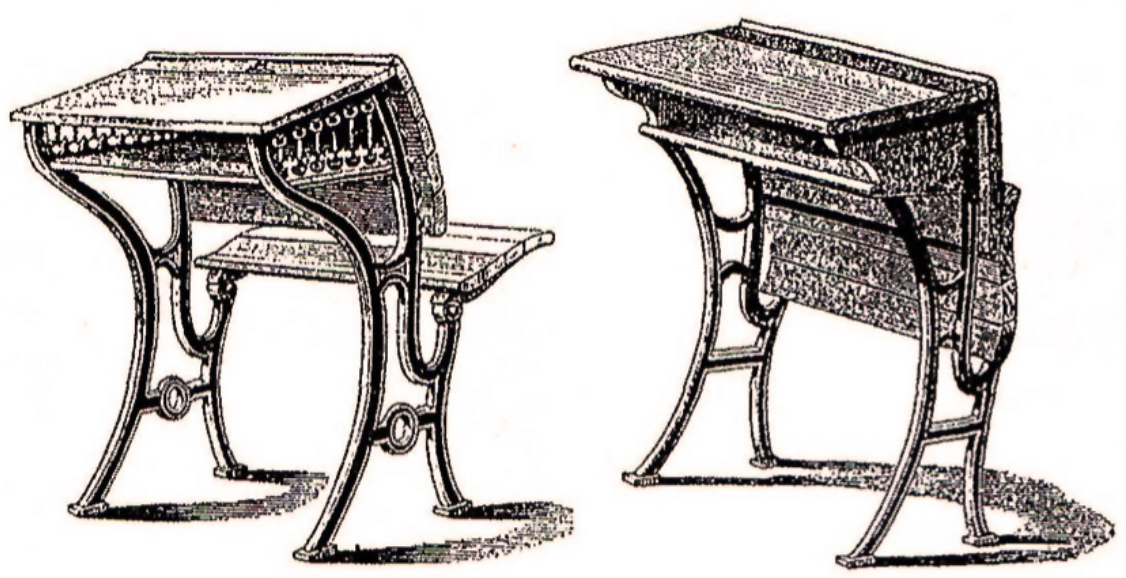

Figura 7 - Da esquerda para direita, sistema Andrew e sistema Stevens. Imagem extraída do livro de Josette Peyranne (2001, p. 138). 
Boston, por sua coleção de carteira. A medalha de mérito, de acordo com Schoroeder-Gudehus e Rasmussen, "recompensa a qualidade e o acabamento do trabalho, a importância da produção, a abertura de novos mercados, o emprego de ferramentas e de máquinas avançadas ou o bom preço dos produtos [...]" (figura 8) $)^{36}$.

Estes modelos possuem assentos independentes equipados com encosto; eles são fixos no chão por um pé de ferro. Os franceses reconhecem a grande solidez do ferro e a originalidade destes modelos, mas consideram muita despesa para que estes mobiliários sejam adotados nas nossas escolas ${ }^{37}$.

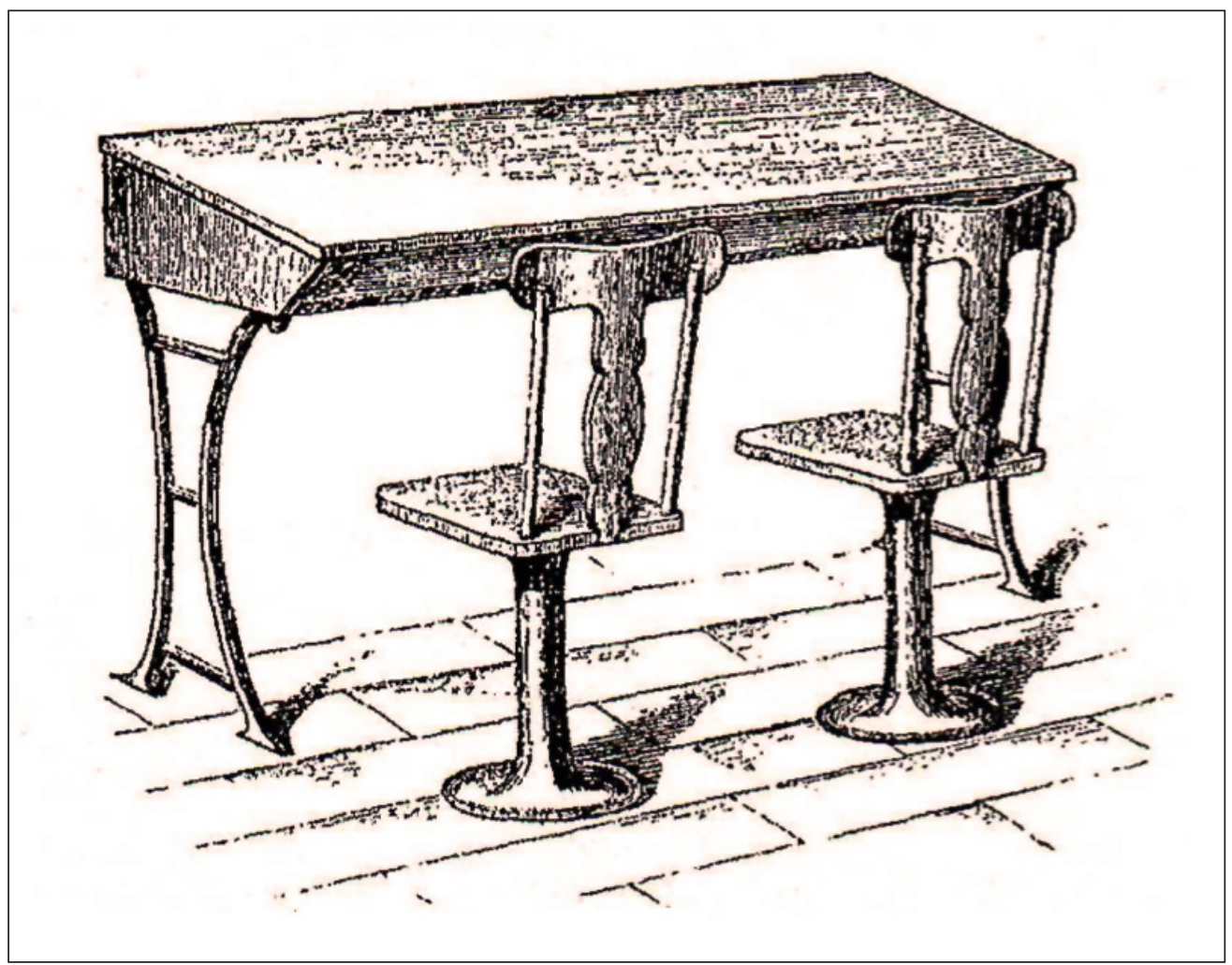

Figura 8 - Carteira de Boston (Sistema Ross). Imagem extraída do livro de Aimé Riant (1 874, p. 121 ).

Além do modelo premiado, no Illustrated Catalogue of Ross'Improved School, Church, and Vestry Furniture ${ }^{38}$, de 1872, constam, dentre outras informações, o material de fabricação das carteiras, suas dimensões e formas de aquisição. As manufaturas são do próprio Joseph L. Ross que tem sua sede em Boston (Massachussets - EUA). Na abertura do Illustrated Catalogue, o proprietário se dirige aos oficiais da escola, professores e educadores explicando que "sempre foi seu objetivo melhorar o mobiliário; e ele agora acredita que, em seus móveis, a perfeição está muito próxima de ser atingida" 39 . Resistência, durabilidade e adequação à idade e à estrutura do escolar são, segundo Ross ${ }^{40}$, as grandes
36. Cf. Brigitte Schoroeder-Gudehus; Anne Rasmussen (1992, p. 88).

37. Cf. Josette Peyranne (2001, p. 139).

38. Ver Joseph L. Ross (1872).

39. Cf. Joseph L. Ross (1872, p.5).

40. Cf. Joseph L. Ross (1872). 
41. Cf. Joseph L. Ross (1872, p.5).

42. Cf. Josette Peyranne (2001, p. 139).

43. Cf. The National School Furniture Co. (1872, p. 5). características desses móveis, combinadas com um estilo de acabamento que não pode ser ultrapassado. A força e a durabilidade são atribuídas à combinação da madeira com o ferro, utilização de operários experientes, máquinas engenhosas e o melhor material.

$\bigcirc$ "designer e manufacturer" de mobiliário escolar ainda informa que a maioria dos móveis foi desenhada por ele mesmo, desde 1847. Isso atesta a durabilidade do trabalho, já que "as escolas que adquiriram o mobiliário naquele ano ainda o têm em uso, com eficiência intacta" ${ }^{\prime \prime}$. Por isso, os móveis Ross são propagados no catálogo como os mais baratos do mercado, quando se conjugam o preço, a qualidade e estilo de acabamento. Outro atrativo é acrescido para aqueles que pretendiam fazer encomendas à distância: a manutenção do preço.

Após as informações de caráter propagandístico, são dadas as instruções de como fazer a encomenda do mobiliário escolar: 1) Devem ser indicadas a altura das mesas e cadeiras e também a quantidade necessária de cada altura, conforme o catálogo; 2) Apesar da existência de estoque, é necessário fazer a solicitação com certo prazo, pois as encomendas são crescentes; 3) Os preços indicados incluem todos os parafusos necessários para as mesas e cadeiras dos alunos; 4) Os tinteiros para as carteiras dos alunos têm preço adicional; 5) No preço é considerado o tipo de madeira utilizado cerejeira ou carvalho, envernizada ou oleada no grão de madeira; 6) $\bigcirc$ encaixotamento terá preço extra. Os catálogos, via de regra, traziam figuras de planos de disposição das carteiras na sala de aula.

Outra importante empresa americana, The National School Furniture Co, propôs um modelo de carteira móvel, com pé de ferro e lugar individual. "A mesa é integrada com o banco do aluno assento à frente, ela dobra-se na parte de trás do assento dianteiro" (figura 9) (2. $^{\text {. }}$

A empresa desenvolvia suas atividades tanto em Nova York, quanto em Chicago, conforme o llustrated Catalogue of New and Improved Styles of School and Church Furniture. $\bigcirc$ catálogo, que data de 1872, portanto um ano antes da exposição de Viena, acrescenta informações importantes sobre o modelo ali exposto. Todas as carteiras tinham o novo assento dobrável, patenteado em 20 de fevereiro de 1872. E conforme costume do comércio, o conjunto do mobiliário escolar é apresentado como o melhor do mercado. $\bigcirc$ modelo apresentado em Viena, The Peard Desk and Settee Combined é descrito como "o mais aprovado estilo de Mobiliário Escolar no Mercado" (figura 10)43.

No texto de introdução do catálogo é manifesta a intenção de fabricar mobiliário para todo o país e também para clientes de outros países. Por isso, foi estabelecida uma fábrica em Chicago, com venda na loja A.S. Barnes \& Co. $\bigcirc$ titular das patentes das carteiras dobráveis era John Peard, supervisor direto do departamento de produção. Conforto e elegância são as características atribuídas às carteiras da The National School Furniture $C^{\circ}$. Semelhante a Ross, a empresa informa que os pedidos devem ser feitos com antecedência devido à grande demanda por parte de escolas e igrejas. 
A quantidade de expositores de cada país que compareciam às exposições permite concluir que o mercado do mobiliário escolar, nas últimas décadas do século XIX, não era desprezível. Da oferta desse objeto dependia a expansão da escola de massa; e, para atender às demandas, cada fábrica e empresa deveria ser eficiente na propaganda dos seus produtos.

The National School Furniture Co, por exemplo, relacionou em seu catálogo nove vantagens de suas carteiras sobre todas as outras no mercado. Essas razões são indicativas tanto do que a indústria do mobiliário podia oferecer, quanto do que a escola e os educadores almejavam encontrar na carteira escolar. Por isso, apesar da vasta lista, é elucidativo apresentá-la:

$1^{\circ}$. Ela economiza espaço. Não há carteira que feche tão compacta - e comodamente, ocupando, quando dobrada, apenas nove polegadas de espaço e que garanta vias de passagem entre as mesas de dois pés e meio. Quando dobrada como Settee a capacidade do assento é um terço maior que a dos estilos comuns.

$2^{\circ}$. Limpeza, uma das considerações mais importantes na sala de aula, é obtida com dificuldade onde a mesa fixa é usada, mas com a Carteira Peard é uma questão de perfeita facilidade garantir uma sala arrumada e limpa; varrer não é mais difícil do que em um salão aberto.

$3^{\circ}$. A prateleira de livro está sempre acessível - uma vantagem não encontrada em nenhuma outra carteira dobrável.

$4^{\circ}$. A dobra da mesa aumenta muito sua durabilidade porque está fora do alcance de danos.
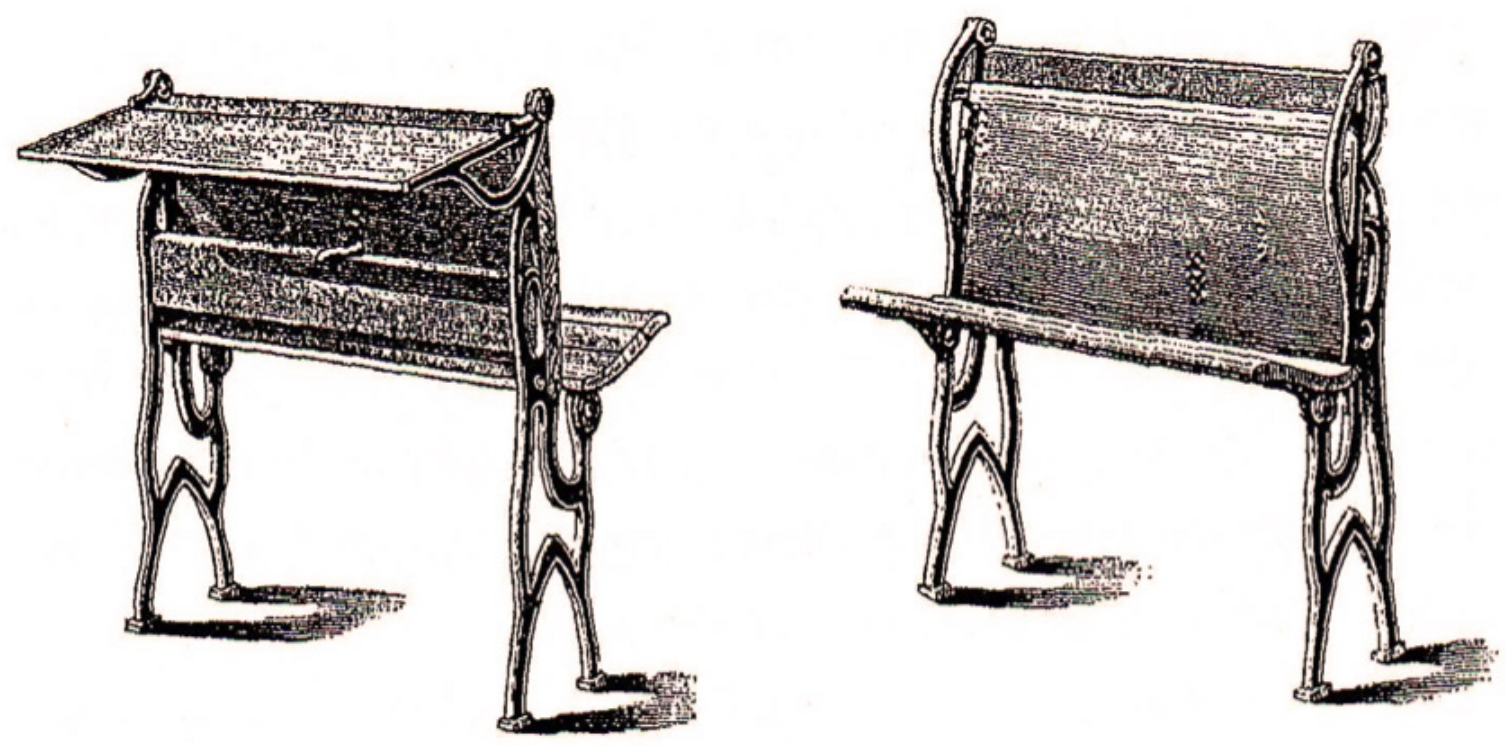

Figura 9 - Carteira da The National School Furniture C ${ }^{\circ}$, de Nova lorque. Imagem extraída do livro de Josette Peyranne (2001, p. 139). 
44. Cf. The National School Furniture Co. (1872, p. 6).

\section{COMPARATIVE SIZES, SHOWING DESK IN DIFFERENT POSITIONS.}

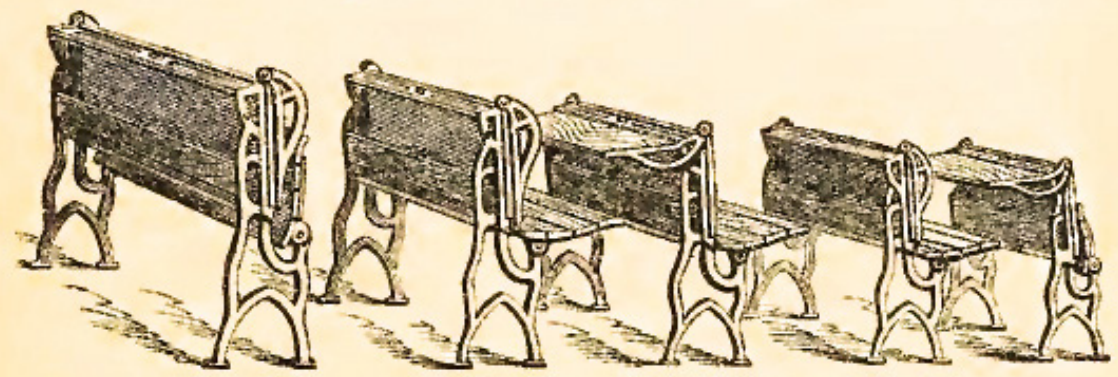

In the ugs of this Dest a School or Lecture-room is secured at pleasure.

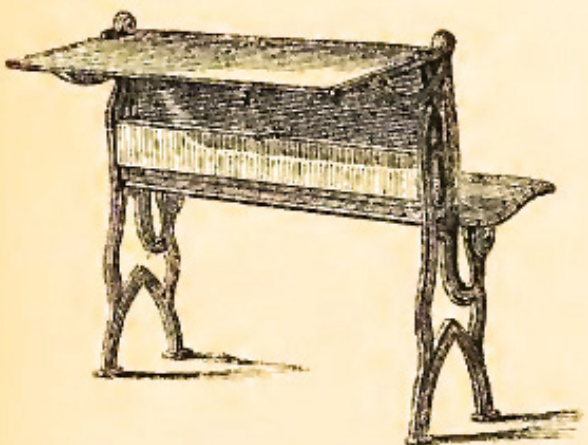

In position for use as Desk and Settee.

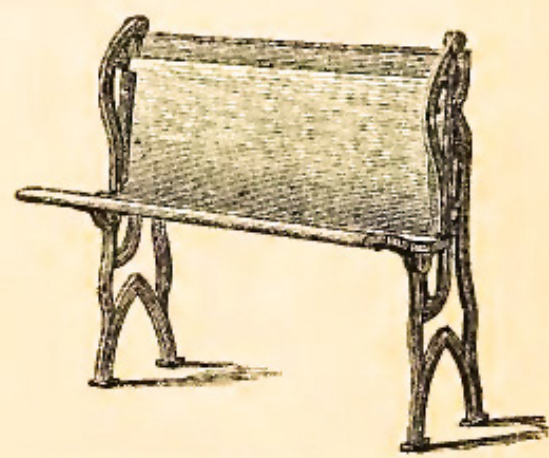

Desí-lid folded for use as Settee only.

Figura 10 - Carteira The Peard Desk and Settee Combined. Imagem extraída do catálogo The National School Furniture Co. (1872, p.50).

$5^{\circ}$. Elas são construídas com referência especial para o conforto e a saúde do aluno e o assento e o encosto são assim moldados para garantir facilidade ao educando que, inconscientemente, é obrigado a assumir uma posição ereta e saudável.

$6^{\circ}$. A dobradiça do assento (nossa patente) é silenciosa e é construída de forma a ser facilmente apertada quando, através do uso longo e contínuo, o assento fica solto e frouxo no cilindro. Assim, um conjunto perfeitamente silencioso é garantido enquanto o mobiliário está em uso. É absolutamente a única dobradiça no mercado que é silenciosa, e continuará a ser assim.

$7^{\circ}$. A escola pode com prazer ser transformada em uma espaçosa, confortável e elegante sala para palestras e reuniões com propósitos para adultos. Em muitas localidades essa é uma das mais importantes características, pois, assim, a Câmara Municipal e a sala de aula são produzidas como resultado de um esforço. Professores de escolas seriadas também vão apreciar essa vantagem, na qual salas de assembleia são necessárias em cada departamento.

$8^{\circ}$. Elas são feitas da melhor madeira seca em estufa, com acabamento elegante; são perfeitamente simples na construção; nenhum mecanismo, como em qualquer outro estilo de carteira dobrável.

$9^{\circ}$. Quando comprar partes das carteiras desejando-as prontas para aparafusar no chão, economizará mais da metade da despesa de frete, levando os Móveis Peard ${ }^{44}$. 
Foram destacadas as vantagens não somente das carteiras, mas das peças fundidas:

Note estas peças fundidas nas seguintes indicações:

$1^{\circ}$. As peças fundidas são de peso extra (sendo 25 por cento mais pesadas do que as de qualquer outra carteira) e são largas para assegurar a maior força possível.

$2^{\circ}$. Os pés sobre os quais as peças fundidas repousam no chão são muito grandes e irão, se desejado, admitir quatro parafusos em cada um, garantindo estabilidade perfeita para a carteira.

$3^{\circ}$. Chamamos especial atenção a nossa Patente de Assento Conjunto (patenteado em 20 de fevereiro de 1872), o qual, por meio de uma aplicação de pastilhas, é totalmente livre de ruído e é, sem exceção, a mais forte dobradiça no mercado. Ela nunca se tornará ruidosa e é o único assento dobrável sobre o qual isso pode ser dito.

$4^{\circ}$. Observe a curva bonita do braço do assento, que alcançamos através do número de lâminas utilizadas.

$5^{\circ}$. Observe o que uma forma compacta da carteira pressupõe quando o braço do assento e o tampo da mesa são dobráveis. Não existem saliências de ferro perigosas deixadas expostas, como é o caso de todas as outras carteiras dobráveis, e o espaço ocupado é apenas de metade de qualquer outro estilo. As vantagens deste mobiliário não podem deixar de ser evidentes para todos os diretores de escola. Não pode-se também exaltá-la muito em sua apreciação ${ }^{45}$.

Segundo a companhia, a carteira Gem Desk combina conforto, elegância e durabilidade, sendo a mais perfeita do mercado (figura 11 ).

Na descrição da The Study Desk, a preocupação é menos com a elegância e mais quanto às questões higiênicas (figura 12):

Como vamos evitar que nossos alunos, inclinando-se sobre seus livros enquanto envolvidos no estudo, evitem a encurvadura dos ombros e a compressão do peito? É um problema que há muito confunde o cérebro de cada educador que tem levado o bem-estar físico dos seus alunos em consideração, mas que finalmente está completamente resolvido com a produção da "The Study Desk", como mostrado nos cortes que acompanha. É uma carteira dobrável com gancho de cavalete integrado, de tal forma que, quando seu tampo é dobrado, o cavalete é apresentado diretamente diante do aluno, permitindo-lhe, quando o livro é colocado sobre a mesa, assumir uma posição fácil e ereta, enquanto que o livro é colocado sobre uma linha com um ângulo de visão sem que seja necessário qualquer encurvatura do pescoço ou da cabeça. Recomendamos essa mesa especialmente para uso em Escola Normal, Ensino Médio e Academias. É muito elegante no acabamento, bem durável e pode se tornar bastante requisitada ${ }^{46}$

Cada carteira possuía um diferencial seja no banco, no encosto, no apoio de pé, na superfície de trabalho, na gradação da altura; e cada um deles servia de elemento de propaganda. The Study Desk é apresentada como a mais aprovada e desejável do mercado para escolas normais, secundárias e academias. No entanto, não possuía elevação do tampo da superfície de trabalho. Essa característica poderia ser encontrada na High and Normal School Desks, como se observa abaixo (figura 13). 
47. Ver Eben. Brewer (1873, p. 99-114).

48. Aqui, optei por manter a ordem da relação conforme aparece no catálogo.

49. Cf. Eben. Brewer (1873, p. 100).

\section{THE GEM DESK}

Is made in Five Sizes, as shown by comparison in Cut below.

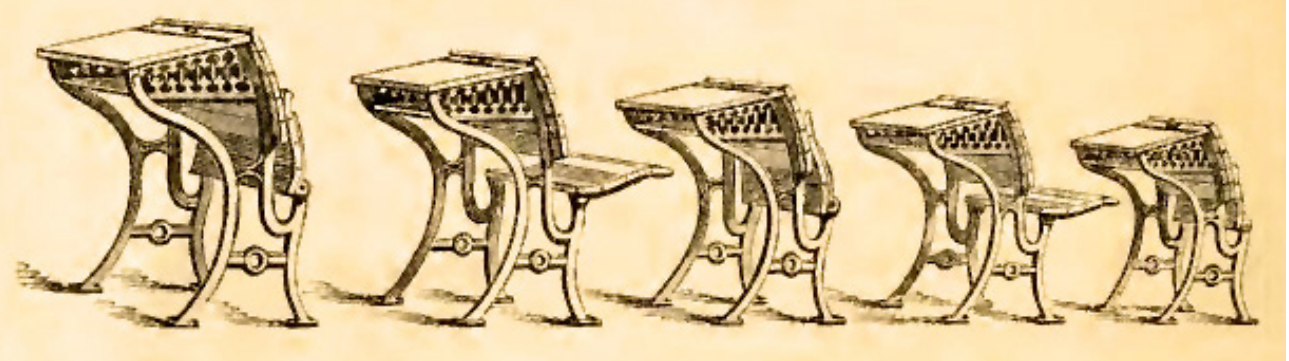

Figura 11 - Carteira The Gem Desk. Imagem extraída do catálogo The National School Furniture Co. (1872, p. 10).

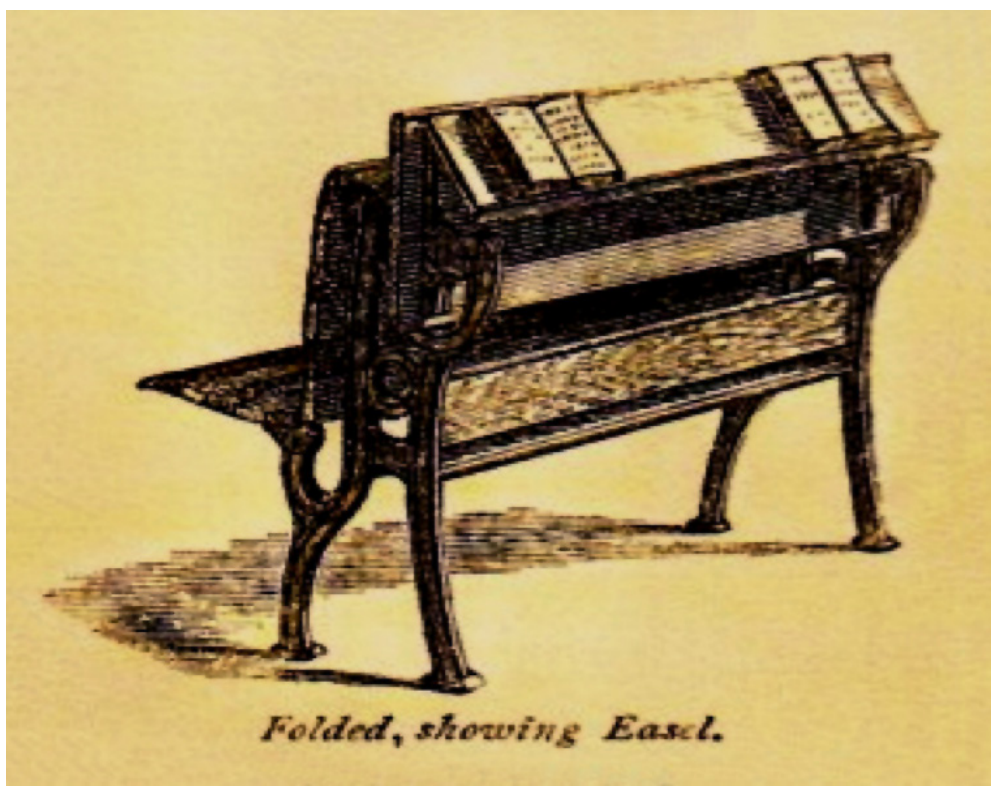

Figura 12 - Carteira The Study Desk. Imagem extraída do catálogo The National School Furniture $\mathrm{C}^{\circ}$. (1872, p. 11$)$.

Por meio do Official Catalogue of the American Department" referente à Viena, tem-se notícia de todos os expositores americanos que, no período, atuavam no ramo do mobiliário escolar. Quais sejam²

a) Relatório de instruções em bairros e cidades, distrito de Boston.

- "Mobiliário de escola compreendendo carteiras simples e cadeiras de duas dimensões e modelos diferentes para os alunos; uma carteira para desenhar, uma mesa de professor com uma carteira para ensinar $[\ldots]^{\prime \prime 4}$. 
Manufacturers of School Furniture, Apparatus, \& C.

b) A. H. Andres \& Co., Chicago, Illinois

Três caixas de mobiliário escolar, carteiras e bancos.

c) National School Furniture Co. New York City

Completo conjunto de móveis para uma sala de aula, incluindo carteiras de professores e 48 carteiras e bancos para alunos.

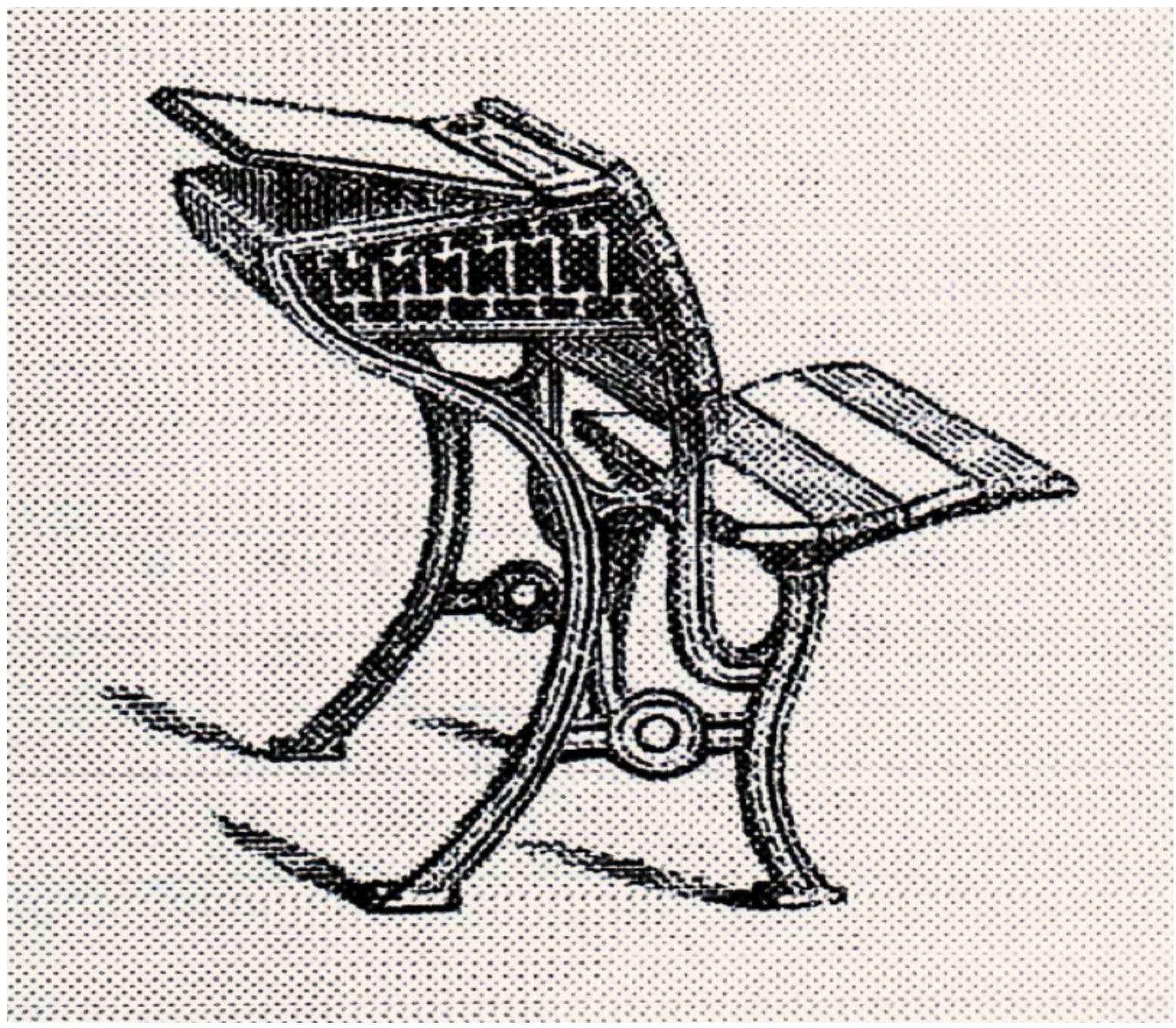

Figura 13 - Carteira High and Normal School Desks. Imagem extraída do catálogo The National School Furniture Co. (1872, p. 13).

d) New-York Silicate Bookslate Co. New York City Ardósias em silicato para as escolas.

e) S. W. Nichols, Boston, Massachusetts.

Uma carteira de parede.

f) H. A. OESTERLE, PHILADELPHIA, Pennsylvania

Conjunto de livros de mão e de bolsas a tiracolo para livros escolares. 
50. Cf. Exposition de 1878 (1878, p. 9). g) ROBERT PATON, New York City

Carteira escolar.

h) H. REFFET, Hoboken, New-Jersey

Moldura fracionada, "Moldura Russa Doppel" e máquina calculadora.

i) JOSEPH L. ROSS, Boston, Massachusetts

Móveis escolares de vários tipos.

i) G. W. SHATTUCK, Boston, Massachusetts

Carteiras escolares, bancos \& C.

k) W. A. SLAYMAKER, Atlanta, Georgia

Carteira escolar e outros móveis.

I) JOHN CHARLES SPARR.

Tinteiro melhorado.

m) F. SOCHNER, Hamilton, Ohio.

Patente Ruler.

n) E.M.THURSTON \& Co. Providence, Rhode Island

Carteira escolar e bancos.

o) OSEPH TROLL, Belleville, Illinois

Telúrio Automático do "Troll".

p) WHITE, R. Boston, Massachusetts

Ventilador patenteado para uso em salas de aula não fornecido com hélices ventilantes.

q) WILLIAMS, T.H. Plymouth, Indiana

Carteira escolar \& C.

A relação de expositores e industriais americanos na exposição de Viena permite o cruzamento de informações com os catálogos produzidos por essas fábricas de mobiliário escolar. Mais que isso, nas exposições, os Estados Unidos não deixam dúvidas quanto ao seu domínio na produção da carteira escolar fazendo com que outros países, na corrida pelo domínio dos mercados, buscassem também seu destaque seja pela semelhança (produção de carteira pé de ferro fundido), seja pela diferença (carteira toda em madeira).

A questão das críticas entre os países pode ser vislumbrada no catálogo sobre Le Mobilier Scolaire a l'Exposition Internationale de 1878, em Paris. Apesar de ser um catálogo de preços do mobiliário do sistema Lenoir, em sua Introdução faz uma abordagem sobre o desenvolvimento do mobiliário escolar até aquele ano, além de uma breve descrição do mobiliário apresentado por outros países.

Para o autor do catálogo, desde a publicação do trabalho do francês Dr. Riant na exposição de 1867, nada novo havia surgido. Essa crítica parecia valer especialmente para os ingleses. Diz ele: "Paramos por um longo tempo na seção ingleza [...] A Inglaterra não aprendeu nada e não tem nada selecionado, pelo menos que nos interessa aqui" 50 . Em páginas anteriores, a crítica foi ainda mais contundente: 
Na Inglaterra, a questão da educação pública permanece estacionada. Parece que a arte do mobiliário escolar tende a se mover somente na direção da desarticulação. Na verdade, a maioria dos objetos móveis descritos nesta seção foram criados por palhaços ${ }^{51}$.

Os fabricantes estrangeiros destacados são da Bélgica, de Luxemburgo, Suíça, Áustria, Dinamarca, Rússia, Suécia, Inglaterra e Canadá, Argentina, Japão e França. Aponta-se o progresso da Bélgica somente para enfatizar a doação que a França fez da carteira sistema Lenoir, àquele país, "[...] após o Congresso de Professores em Bruxelas em 1875"52.

mobiliário do sistema Lenoir é apresentado como o que havia de melhor no ramo, pois "nós vimos a Exposição de 1867, a de Viena e Filadélfia, todos vimos os mesmos estudos e erros, os esforços infrutíferos que encontramos, para nossa surpresa, na Exposição de 1878"53.

O objetivo do texto introdutório Catalogue Le Mobilier Scolaire a l'Exposition Internationale de 1878 - Systema Lenoir é fazer uma breve descrição dos tipos de carteira apresentados pelos países acima citados, uma exaltação ao sistema Lenoir e uma depreciação das carteiras inglesas.

Na França, como em outros lugares, não nos podemos permitir envolver em perpétuas mudanças ou substituições de mobiliário. É o dinheiro público que lhes paga. Estamos trabalhando desde o princípio para unir o sólido ao útil, guardando-nos de esquecer a elegância e simplicidade da aparência. $\bigcirc$ mobiliário inglês nunca foi projetado para as salas de aula. Ele é imaginado, construído e tratado como façanhas de engenhosidade, que aqui e acolá um colecionador ou um museu pedagógico quer admitir em sua coleção ${ }^{54}$

As carteiras do sistema Lenoir, ao contrário, preenchiam os seguintes objetivos:

A altura da mesa e banco, a rígida observação dos ângulos retos, infligidas aos alunos mais ou menos formados parece uma ideia um pouco fantasiosa. Assumimos com razão que estudantes de todas as idades, de todo tamanho, mais ou menos formados, chegam juntos ao mesmo nível de instrução. Então, o ensino do mesmo grau comportaria uma diferença de mobiliário relacionada com o tamanho de cada um. Esta aplicação, com base em cálculos de risco e até mesmo quimérico de estatura ou de leis de equilíbrio, é uma visão. $\bigcirc$ mais importante é oferecer para o aluno, quer ele seja pequeno, raquítico ou mesmo disforme, quer seja dotado de uma bela e grande estatura, os meios de estudo uniformemente cômodos ${ }^{55}$.

Apesar das disputas entre franceses e ingleses em assuntos que extrapolavam o mercado do mobiliário escolar e, concomitantemente, o atingia, o grande rival continuavam sendo os Estados Unidos, como se reconhece nesse documento.

Por mais de vinte anos, a questão do mobiliário escolar foi suscitada nos Estados Unidos. Desde então, outros países se dedicaram ao estudo científico desta importante questão no desenvolvimento das escolas em termos de higiene e bom ensino. $\bigcirc$ mobiliário para escolas tornou-se então objeto de atenção por todas as nações preocupadas com a emulação louvá-
51. Cf. Exposition de 1878 (1878, p. 8).

52. Cf. Exposition de 1878 (1878, p. 6).

53. Cf. Exposition de 1878 (1878, p. 12)

54. Cf. Exposition de 1878 (1878, p. 9).

55. Cf. Exposition de 1878 (1878, p. 10). 
56. Cf. Exposition de 1878 (1878, p. 13).

57. Cf. Exposition de 1878 (1878, p. 14).

58. Cf. Josette Peyranne (2001, p. 132). vel. Esta preocupação geral teve o efeito imediato de fazer emergir uma indústria especial, aquela da fabricação do mobiliário escolar ${ }^{56}$.

Segundo A. Lenoir, a França, somente em 1867, na exposição universal, viu nascer, entre sistemas anormais e pretensiosos, "a grande razão de adaptar o banco à criança e não mais a criança ao banco. Vimos aparecer a solução do problema no objeto do sistema Lenoir [que] tomou seu lugar à frente do progresso" (figura 14) ${ }^{57}$.

Embora o autor do Catalogue Le Mobilier Scolaire a l'Exposition Internationale de 1878 estabeleça 1876 como marco dos primeiros resultados da instrução pública francesa, no domínio do mobiliário escolar, Peyranne afirma que "nenhum comentário é feito ao mobiliário francês"58 nessa exposição. Todavia, como os demais países, a França queria concorrer com os Estados Unidos pelo rentável mercado do mobiliário escolar.

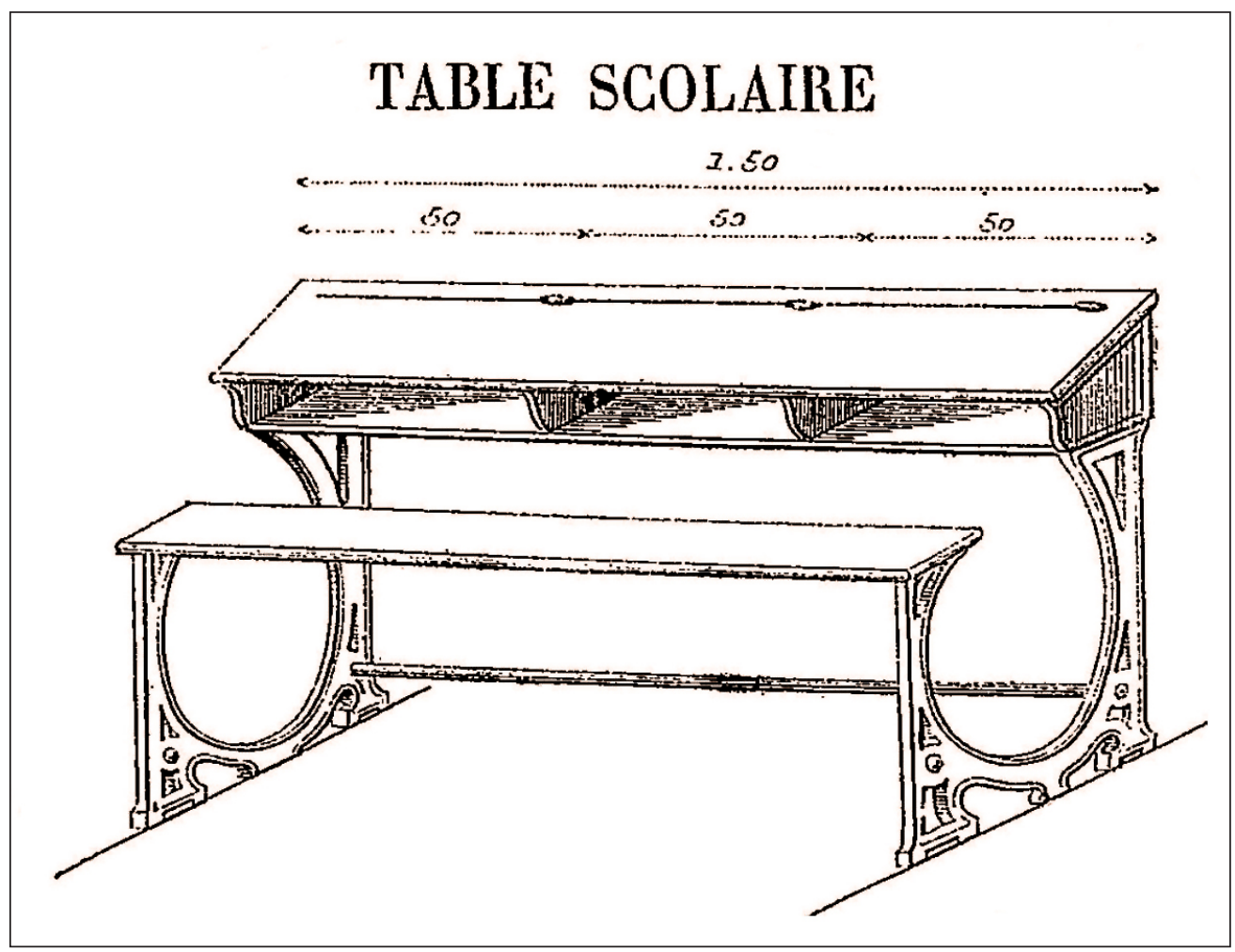

Figura 14 - Carteira Sistema Lenoir. Imagem extraída do livro Le Mobilier Scolaire à l'Exposition Internationale de 1878 (1878, p. 17). Exposition de 1878. Bibliothèque Nationale de France.

O lugar de destaque que o mobiliário escolar adquiriu nas exposições universais sinaliza que a escola ganhou a atenção não somente dos Estados, mas da indústria que viu nela um poderoso mercado consumidor. Daí, a quantidade de fábricas especializadas na produção de diferentes modelos de carteira. 
Segundo Lawn e Grosvenor "[...] há um discurso poderoso sobre a escola como lugar de consumo, crescente ao longo de décadas, especialmente em períodos de construção e de inovação escolares, mas presente agora na nova forma de encarar a educação como um serviço lucrativo" 59 .

Com isso, empresas comerciais reconheceram a escola como lugar de publicidade e de desenvolvimento de novos clientes ${ }^{60}$. Fazendo uma exploração histórica das exibições educacionais lan Grosvenor ${ }^{61}$ afirma que "educação no mundo contemporâneo significa negócios". As exposições, para ele, permitem pensar a relação entre educação e consumo e têm um papel importante na promoção de ideias educacionais, objetos e práticas. "A proposta era 'ver' e através do ver, acreditar e, acreditando, ter um modelo de uma boa prática para seguir"62.

Cada empresa objetivava que os clientes acreditassem no seu modelo de carteira como o mais inovador e higiênico. A respeito dessas disputas no âmbito das Exposições, Josette Peyranne ${ }^{63}$ afirma:

Estas primeiras Exposições são muito inovadoras nos mobiliários apresentados. Cada país desejava ser referência neste domínio. Eles se copiavam, criticavam, concebiam, propunham claramente, tentavam vender. As várias honras e os prêmios distribuídos na Exposição de Viena traduzem o novo interesse em relação à carteira. De fato, mobiliário escolar é uma parte integrante da sociedade infantil escolarizada de meados do século XIX.

Proteger suas invenções de cópias era fundamental para a sobrevivência das empresas. A busca pela conquista de novos mercados consumidores se torna evidente nas exposições universais e, a Exposição de 1873, em Viena, é exemplar a esse respeito. Entretanto, para entender a corrida dos países, sobretudo Estados Unidos e França, pela hegemonia no mercado de mobiliário escolar, é preciso não desconsiderar as patentes de carteira escolar.

Patentes e empresas norte-americanas e francesas de mobiliário escolar

Abordar a questão das patentes é elucidativo para o problema aqui proposto, pois ela evidencia, de modo ímpar, a estreita relação que se foi estabelecendo, a partir da segunda metade do século XIX, entre escola e indústria; a emergência da escola como importante mercado consumidor; e a transnacionalização dos objetos escolares, no caso, as carteiras, cujos modelos poderiam ser plagiados por pessoas do mundo inteiro.

A proteção dos direitos de propriedade intelectual tem início no fim do século XIX, com as convenções de Paris (1883 - Propriedade Industrial) e Berna (1886 - Obras Literárias e Artísticas), ambas com fins preponderantemente jurídicos ${ }^{64}$. Das invenções dependiam não só "a expansão industrial e tecnológica" 65 , mas também o domínio de um setor do mercado por um país ou uma empresa. "O aumento da proteção do direito de
59. Cf. Martin Lawn e Ian Grosvenor (2005, p. 8).

60. Ver Martin Lawn (2005).

61. Cf. Ian Grosvenor, (2005, p. 165).

62. Cf. Ian Grosvenor, (2005, p. 174).

63. Cf. Josette Peyranne (2001, p.141).

64. Ver Maristela Basso (2000).

65. CF. Maristela Basso (2000, p. 23). 
66. CF. Maristela Basso (2000, p. 26).

67. CF. Maristela Basso (2000, p. 69).

68. Cf. The National School Furniture Co. (1872, p. 7).

69. Cf. The National School Furniture Co. (1872, p. 12).

70. Cf. The National School Furniture Co. (1872, p. 12). propriedade intelectual e a certeza da proteção ensejaram o incremento do poder do mercado e o desenvolvimento do comércio internacional" 66 .

No fim do século XIX, a expressão "propriedade industrial" designaria

os direitos privados para defesa da indústria e do comércio, como os direitos de patentes, de desenhos e modelos de fábrica ou ornamentais, desenhos e modelos de utilidade e marcas, defesa contra a concorrência desleal e contra as falsas indicações de proveniência dos produtos e outras regras afins ${ }^{67}$.

A descrição, muitas vezes minuciosa, das carteiras, de sua fabricação e peças nas exposições e catálogos servia como poderosa ferramenta de propaganda, mas gerava como efeitos colaterais, a possibilidade e a realidade do plágio, da cópia dos modelos por marceneiros e outras empresas, de pequeno porte ou não. Poderiam os visitantes das exposições ou aqueles que tivessem acesso aos catálogos, como por exemplo, educadores de diversos países, de posse dos desenhos das carteiras, mandar reproduzi-las, lançando mão de uma opção local mais barata e com menor custo de frete. Essa opção, via de regra, eram os marceneiros, que também se proliferavam com a expansão das cidades nas últimas décadas do século XIX e início do XX.

Não é por acaso que muitas indústrias e fábricas de mobiliário escolar possuem patentes de suas carteiras e não hesitam em mencionar nos catálogos as punições e processos nas quais incorreriam aqueles que assim procedessem. Com isso, o público é advertido:

$\bigcirc$ público está prevenido contra as produções ou as compras de qualquer mobiliário escolar com o tampo da carteira virado contra o encosto do banco, então formando o assento, presente em outras que não a Perad's, bem como contra todas as demais infrações em suas patentes; e aqueles que venderam ou compraram serão processados de acordo com as penas da lei68.

Outra forma de abrir novos mercados nos países mais distantes era oferecer carteiras com custo mais baixo, mantendo algumas características do mobiliário mais sofisticado, porém com material inferior. É o caso da The Economic Desk, produto da The National School Furniture $C^{\circ}$, para aqueles que desejassem "um estilo barato e ainda substancial de mobiliário"69.

O assento dessa carteira era feito de ripas, curvado, dobrável, com a mesma articulação conjunta e silenciosa das melhores mesas. "Nós fornecemos esta carteira a um preço 20 por cento menor que a de nossos estilos regulares e muito abaixo do preço de qualquer outra carteira fabricada"70. Na pretensão dos fabricantes, era um modelo para desafiar e dispensar qualquer competidor.

A questão da propriedade industrial estava de tal modo vinculada às exposições universais que, em 1889, houve, no âmbito da Exposição Universal de Paris, o Congresso Internacional da Propriedade Industrial, na mesma cidade, sob a direção do Ministério do Comércio, da Indústria e das Colônias francês. 
A patente é um privilégio de invenção cuja concessão tem como um dos requisitos a industriabilidade. "A invenção deve ser suscetível de exploração industrial. Deve ter utilidade"71. Em outras palavras, "a industriabilidade é a qualidade da invenção de permitir uma aplicação industrial, isto é, de ser utilizada em um ramo qualquer de produção"72.

Esse "diploma oficial que assegura o monopólio da exploração do invento"73 é de suma relevância para a indústria e para o inventor.

A patente confere ao seu titular o direito de impedir terceiro, sem o seu consentimento, de produzir, usar, colocar à venda, vender ou importar com estes propósitos: I - produto objeto de patente; II - processo ou produto obtido diretamente por processo patenteado ${ }^{74}$.

Pode-se imaginar a importância desse instituto no contexto das exposições universais e da expansão da escola de massa no mundo ocidental. A circulação dos catálogos pelo mundo fazia parte do procedimento para venda e aquisição das carteiras e outros objetos escolares em países distantes. Os catálogos eram enviados às escolas ou entregues pelos representantes e agentes comerciais, os quais intermediavam toda a operação de compra e venda.

É o que ocorre em 21 de novembro de 1894, quando o diretor da Escola Normal de São Paulo, Gabriel Prestes, envia ao Secretário de Estado dos Negócios do Interior, Cesário Motta Junior, a relação dos instrumentos para o ensino de mecânica e astronomia elementar, conforme tipos e preços extraídos "do Catálogo da ancienne Maison Rousseau"75. O diretor pede no ofício autorização para fazer diretamente a encomenda.

$\bigcirc$ pedido é atendido, pois em 4 de dezembro do mesmo ano, Gabriel Prestes escreve ao representante comercial da Maison Rousseau, Charles Vautelet, encarregando-o do fornecimento dos instrumentos "o mais breve possível, nas condições das outras encomendas anteriormente feitas, recomendando porém que o "Theodolito de Gurley" seja americano, que corresponde ao numero 8 do catálogo da Casa W.L.E. Gurley (Troy Inglaterra)"76.

Os catálogos eram imprescindíveis para as compras à distância. Como já afirmado, não seria difícil qualquer Estado ou proprietário de escola particular contratar um marceneiro ou indústria local para reprodução dos "melhores" modelos de carteira escolar. Os Estados Unidos logo tomaram providências para solucionar esse problema.

Em 1870, muitas indústrias de carteira escolar norte-americanas já possuíam patentes de seus produtos - patentes dos tinteiros, assentos dobráveis, dentre outros. Nos Estados Unidos, "em 1787, sua Constituição assegurou o direito dos inventos como um estímulo ao desenvolvimento industrial"77. Referência mundial no ramo, quais as novidades produzidas pelas indústrias americanas de mobiliário escolar?

A empresa Geo \& C. W. Sherwood, em seu catálogo de 1864, destaca um elemento patenteado da Pupils' desks. "Esta carteira é bem acabada, geralmente feita de cerejeira, produzida com nosso tinteiro patenteado, parafusos de fixação, tudo completo"78.
71. Cf. Rubens Requião (2011, p. 366).

72. Cf. Rubens Requião (2011, p. 367).

73. Cf. Rubens Requião (2011, p. 360).

74. Cf. Rubens Requião (2011, p. 373).

75. Ofício n. 110. Acervo Histórico da Caetano de Campos em São Paulo. Correspondência da Diretoria (1893-1895).

76. Ofício n. 115. Acervo Histórico da Caetano de Campos em São Paulo. Correspondência da Diretoria (1893-1895).

77. Cf. Rubens Requião (2011, p. 361).

78. Cf. Geo. \& C. W. Sherwood (1864, p. 8). 
79. Cf. Joseph L. Ross (1872, p. 51).

80. CF. J.A.Bancroft \& Co. (1870, p. 17).

81. Cf. J. C. Brooke (1884, p.8).

82. Cf. Union School Furniture Company (1889, p. 4).

83. Cf. Union School Furniture Company (1889, p. 4).

84. Cf. Union School Furniture Company (1889, p. 4).

85. Cf. The National School Furniture Co. (1872, p. 12).
Joseph L. Ross era outro importante negociante americano do ramo de carteira. Ele também obteve a patente de um tinteiro. "O melhor em uso! Superior a qualquer tinteiro usado até então e possui todos os méritos atribuídos a ele"79.

A Casa de Mobiliário Escolar J.A.Bancroft \& Co., de igual modo, arrogava para si o melhor tinteiro patenteado - o "Andrew's New Patent Ink Well". "O novo e melhor tinteiro que não só combina as excelências e as soluções dos defeitos daqueles atualmente em uso, mas que também adiciona vários recursos novos e importantes, nunca antes vistos" 80 . Além do tinteiro, havia duas carteiras patenteadas, como Soper's Patent School Desk e Andrews' Patent Graduated Desk. Nota-se que a patente agregava de tal forma valor ao produto que passava a compor o nome do mesmo.

Algumas empresas americanas produziam mobiliário tanto para a escola como para igrejas. É o caso da J.C. BROOKE Manufacturers. Sua principal carteira era a New Excelsior Desk, feita em seis tamanhos. "A dobradiça do assento é certamente a melhor no mercado, patenteada em 8 de abril de 1879. Ela funciona perfeitamente, de forma suave e sem fazer barulho" ${ }^{\prime \prime 1}$.

A Union School Furniture Company, na propaganda de sua carteira Automatic, também destaca a dobradiça, assegurando que é uma carteira notável, pois

embora no mercado há relativamente pouco tempo, ela já foi adotada por muitas das principais escolas do país, e já conquistou o seu caminho em Estados distantes e em outros países. Ela cria entusiasmo sempre que apresentada, não só porque é nova, mas porque é tão obviamente superior, em princípio, e em construção do que qualquer outro banco. Desde que os assentos rebatíveis foram inventados, o problema tem sido o de melhorar a dobradiça ${ }^{82}$.

A Union School Furniture Company promete ter resolvido o problema, de que é prova sua patente da dobradiça do assento. Segundo a empresa, as insatisfações permanecem quanto aos assentos das carteiras de outros fabricantes, embora prometam "vários dispositivos a fim de tornar a articulação mais forte, menos suscetível ao desgaste e menos ruidosa"83. Na Automatic, "toda dificuldade é afastada [...] Não há mais fraqueza, flacidez, movimento desajeitado e ruído. Há, em vez disso, resistência, durabilidade, um movimento natural, fácil, e nenhum ruído" 84 .

O catálogo dessa empresa é de 1889, mas nele não é possível identificar de que ano é a patente da dobradiça tão aclamada. $\bigcirc$ emprego da dobradiça parece ter sido uma atrativa inovação técnica que tornava a carteira com assento dobrável diferenciada. Em 1872, The National School Furniture $C^{\circ}$., também obteve a patente de seus assentos dobráveis. Essa informação encontra-se em uma nota inicial de advertência ao público quanto a

Certos vendedores inescrupulosos de móveis comuns que estão se esforçando para impressionar a comunidade com a ideia de que eles controlam todas as combinações de elevação do assento. Advertimos o público contra essa fraude audaciosa e insistimos nas vantagens de nossos assentos integrados ${ }^{85}$ 
Do excerto acima se depreende que o industrial, ao explicitar que o seu produto, ou parte dele, era patenteado tinha em vista não somente sua proteção. A patente era um elemento de vantagem na corrida pela garantia e pela conquista de mercado.

Os Estados Unidos estavam tão à frente na produção industrial do mobiliário escolar que, ainda em 2 de fevereiro de 1869, foi patenteada a Peard's Desk. John Peard era o titular da patente da carteira dobrável e também o supervisor do departamento de produção da The National School Furniture C ${ }^{\circ}$. A Sterling School Furniture $C^{\circ}$. possuía uma dobradiça patenteada na carteira The Peerless ${ }^{86}$.

$\bigcirc$ grande adversário das carteiras dobráveis era o tempo, que as deixava barulhentas e desconfortáveis. A Peard's Desk foi "construída para ser facilmente apertada ao longo do tempo"87. Por isso, "é absolutamente a única dobradiça silenciosa do mercado, e continuará a ser assim".

Diversas patentes podiam ir se justapondo em um mesmo produto, pois a novidade poderia estar em suas engrenagens e partes. No caso da Peard's Desk, em 20 de fevereiro de 1872, foi patenteado seu assento integrado. Apesar da patente já implicar em proibição a terceiros de "produzir, usar, colocar à venda, vender ou importar com estes propósitos produto objeto de patente" 88 , em seus catálogos, muitos industriais reforçam as punições a que estariam sujeitos aqueles que assim procedessem.

O público está prevenido contra as produções ou as compra de qualquer mobiliário escolar com o tampo da mesa rebatível contra o encosto do banco formando, assim, o assento, presente em outras que não a Peard's, bem como contra todas as demais infrações em suas patentes; e aqueles que venderem ou comprarem serão processados de acordo com as penas da lei ${ }^{89}$.

Essa empresa possuía outra carteira patenteada em 23 de maio de 1871, The Study Desk. Sua armação tinha a finalidade de evitar a "encurvatura dos ombros e compressão do tórax" ${ }^{\prime \prime 0}$.

Isso porque as questões ergonômicas e higiênicas não eram alvo somente das preocupações de educadores, médicos e higienistas. "Para os higienistas, o corpo é uma máquina produtora de energia, em seu desenvolvimento, esperamos regenerar a raça" ${ }^{\prime \prime 1}$. O discurso sobre o corpo do cidadão também era utilizado como meio de propaganda das carteiras - um produto que não gerava deformidades no corpo da criança.

No caso francês, foi patenteada, por exemplo, a Nouvelle Table Scolaire, de $M$. Lhuillier ${ }^{92}$. São três as características destacadas nesta carteira: a higiene, a moralidade e a comodidade. Ela satisfazia "plenamente todas as exigências da boa higiene [...] contribui para o desenvolvimento normal do corpo e das faculdades físicas da criança". No aspecto moral, apesar de ter dois lugares, "os assentos são separados por uma caixa que isola os ocupantes"93. $\bigcirc$ mais importante, "a parte de baixo da mesa é sem proteção, a criança permanece descoberta e nenhum de seus movimentos pode escapar aos olhos atentos do mestre" 94 .
86. Ver Sterling School Furniture Co. (1875, p. 4).

87. Cf. The National School Furniture Co. (1872, p. 6).

88. Cf. The National School Furniture Co. (1872, p. 7).

89. Cf. The National School Furniture Co. (1872, p. 7).

90. Cf. The National School Furniture Co. (1872, p. 11).

91. Cf. Josette Peyranne (2001, p. 105).

92. CF. Charles Delagrave (1890, p. 4).

93. CF. Charles Delagrave (1890, p. 4).

94. CF. Charles Delagrave (1890, p. 4). 
95. CF. Josette Peyranne (2001, p. 104)

96. Cf. Josette Peyranne (2001, p. 104, 105).
Embaixo da carteira, sempre foi o lugar da subversão do aluno. Embaixo da carteira pode ser o lugar da "cola", mas não era essa a preocupação no século XIX. "A masturbação era um problema na sociedade do século XIX"95. Era considerada uma degeneração. Controlando o corpo do aluno, intentava-se "regenerar a raça", por isso, a necessidade de uma carteira que oferecesse como vantagem a moralidade, a possibilidade do professor controlar esse "vício", "mortal e contagioso".

A masturbação, longe de ser um problema isolado é um problema social: "descobrimos, há alguns anos, em uma cidade, uma sociedade inteira de rapazes entre 14 e 15 anos que se reuniam para praticar esse vício e toda a escola foi infectada" (S. Tissot, 1864). A criança que se entrega a esta prática funesta e facilmente reconhecida, o crescimento se dá de uma maneira viciosa ou incompleta: o diâmetro do peito se encolhe; o tamanho sofre, às vezes, curvas inadequadas, e se produz no desenvolvimento desarmonias também prejudiciais à regularidade das formas que mantém a saúde ${ }^{96}$.

O professor poderia perceber esses sinais do "masturbador" e, nessa tarefa, o design da carteira poderia ajudar ou atrapalhar. A propaganda da carteira de M. Lhuillier no Catalogue Delagrave é exemplar da relação intrínseca entre economia, higiene e educação na expansão da escola de massa e dos sistemas de instrução pública.

Pelo que se sabe até aqui, a primeira patente de carteira escolar no Brasil, foi concedida a Amando de Araújo Cintra Vidal, em 1889. A partir desse ano até 1907, localizei 20 pedidos de privilégio para carteira escolar, como se vê na tabela, a seguir (tabela 1).

Tais dados demonstram a forte concorrência não apenas das grandes fábricas americanas e francesas, mas também de empresas e fabricantes nacionais. Sinalizam também uma efervescência no mercado de mobiliário escolar no país nas últimas décadas do século XIX. Tanto pessoas físicas quanto pessoas jurídicas investiam no referido mercado. Na tabela 1, as letras "F" e "J" que seguem os nomes dos autores e requerentes devem ser lidas, respectivamente, como pessoa física e pessoa jurídica. $\bigcirc$ Brasil não se insere nessa problemática da criação das condições físicas de funcionamento das escolas como um reprodutor de modelos de carteiras apresentadas nas exposições universais. É como inventor e protagonista que o país se manifesta, tanto no mercado, quanto nas exposições universais e locais, como discorrerei a seguir.

Primeira Exposição Pedagógica do Rio de Janeiro (1883)

Associados às exposições universais, os congressos nacionais e internacionais de educação também contribuíram significativamente para os processos de modernização dos equipamentos da escola. O Brasil não somente participou das exposições universais, pedagógicas e dos congressos de instrução, como também os 
Tabela 1: Patentes de carteira escolar concedidas no Brasil

\begin{tabular}{|c|c|c|c|c|c|c|}
\hline DESCRIÇÃO & AUTOR & DOMICÍLIO & REQUERENTE & $\begin{array}{l}\text { RELATÓRIO/ } \\
\text { ANO }\end{array}$ & REGISTRO & PATENTE \\
\hline $\begin{array}{l}\text { 1. Carteira para uso } \\
\text { de escolas e colé- } \\
\text { gios, denominada } \\
\text { Aparelho Mechani- } \\
\text { co Amando }\end{array}$ & $\begin{array}{l}\text { VIDAL, Amando } \\
\text { de Araújo Cintra } \\
\text { (F) }\end{array}$ & $\begin{array}{c}\text { Brasil, [Rio de } \\
\text { Janeiro - RJ }\end{array}$ & $\begin{array}{l}\text { VIDAL, Amando } \\
\text { de Araújo Cintra } \\
\text { (F) }\end{array}$ & $\begin{array}{l}\text { Rio de Janeiro, } \\
31 / 10 / 1889\end{array}$ & 1128 & 792 \\
\hline $\begin{array}{c}\text { 2. Móvel denomina- } \\
\text { do Banco-Carteira } \\
\text { Escolar }\end{array}$ & $\begin{array}{c}\text { CARVALHO, } \\
\text { Bernardo Pereira } \\
\text { de }(F)\end{array}$ & $?$ & $\begin{array}{c}\text { CARVALHO, } \\
\text { Bernardo Pereira } \\
\text { de }(F)\end{array}$ & $\begin{array}{l}\text { Rio de Janeiro, } \\
\text { 08/06/1894; } \\
\text { Rio de Janeiro, } \\
02 / 06 / 1902\end{array}$ & $?$ & 1748 \\
\hline $\begin{array}{l}\text { 3. Banco-carteira es- } \\
\text { colar aperfeiçoado } \\
\text { denominado Banco } \\
\text { Auler. }\end{array}$ & $\begin{array}{c}\text { AULER, Cristóvão } \\
\text { William (F) }\end{array}$ & $\begin{array}{c}\text { Brasil, Rio de } \\
\text { Janeiro, RJ }\end{array}$ & $\begin{array}{l}\text { Jules Géraud \& } \\
\text { Leclerc (PROC) (U) }\end{array}$ & $\begin{array}{l}\text { Rio de Janeiro, } \\
14 / 01 / 1896\end{array}$ & 2875 & $\begin{array}{c}\text { Patente } 1996 \\
\text { Decreto } \\
28 / 01 / 1896\end{array}$ \\
\hline $\begin{array}{l}\text { 4. Sistema aperfei- } \\
\text { çoado de carteira e } \\
\text { cadeira escolares. }\end{array}$ & $\begin{array}{l}\text { WALLER, Eduardo } \\
\qquad(\mathrm{F})\end{array}$ & $\begin{array}{c}\text { Brasil, São Paulo } \\
\text { - SP }\end{array}$ & $\begin{array}{l}\text { Jules Géraud \& } \\
\text { Leclerc (PROC) (U) }\end{array}$ & $\begin{array}{l}\text { Rio de Janeiro, } \\
\text { 10/02/1896 }\end{array}$ & 2894 & $\begin{array}{c}\text { Patente } 2012 \\
\text { Decreto } \\
\text { 19/02/1896 }\end{array}$ \\
\hline $\begin{array}{l}\text { 5. Banco-carteira, } \\
\text { denominada Paulis- } \\
\text { ta, para serviço de } \\
\text { escolas. }\end{array}$ & $\begin{array}{c}\text { MARAGLIANO, } \\
\text { José (F) }\end{array}$ & $\begin{array}{c}\text { Brasil, São Paulo } \\
\text { - SP }\end{array}$ & $\begin{array}{l}\text { Jules Géraud \& } \\
\text { Leclerc (PROC) (U) }\end{array}$ & $\begin{array}{l}\text { Rio de Janeiro, } \\
23 / 06 / 1896\end{array}$ & 2980 & $\begin{array}{c}\text { Patente } 2077 \\
\text { Decreto } \\
\text { 13/07/1896 }\end{array}$ \\
\hline $\begin{array}{l}\text { 6. Banco-carteira } \\
\text { denominado Adria- } \\
\text { no Nogueira }\end{array}$ & $\begin{array}{l}\text { NOGUEIRA, } \\
\text { Adriano Júlio dos } \\
\text { Santos }(F)\end{array}$ & $\begin{array}{l}\text { Brasil, Rio de } \\
\text { Janeiro - RJ }\end{array}$ & $\begin{array}{l}\text { Jules Géraud \& } \\
\text { Leclerc (PROC) (U) }\end{array}$ & $\begin{array}{l}\text { Rio de Janeiro, } \\
08 / 12 / 1896\end{array}$ & 3110 & $\begin{array}{c}\text { Patente } 2172 \\
\text { Decreto } \\
21 / 12 / 1896 \\
\end{array}$ \\
\hline $\begin{array}{l}\text { 7. Sistema de cartei- } \\
\text { ra, para uso das es- } \\
\text { colas, denominada } \\
\text { Carteira Progresso }\end{array}$ & $\begin{array}{l}\text { CARVALHO, João } \\
\text { Paulo B. de (F) }\end{array}$ & $\begin{array}{l}\text { Brasil, Rio de } \\
\text { Janeiro - RJ }\end{array}$ & $\begin{array}{l}\text { Jules Géraud \& } \\
\text { Leclerc (PROC) (U) }\end{array}$ & $\begin{array}{l}\text { Rio de Janeiro, } \\
14 / 09 / 1897\end{array}$ & 3398 & $\begin{array}{c}\text { Patente } 2373 \\
\text { Decreto } \\
14 / 10 / 1897\end{array}$ \\
\hline $\begin{array}{l}\text { 8. Carteira escolar } \\
15 \text { de novembro }\end{array}$ & PERRY, Luis (F) & ? & PERRY, Luis (F) & $\begin{array}{l}\text { Rio de Janeiro, } \\
09 / 11 / 1897\end{array}$ & $?$ & 2411 \\
\hline $\begin{array}{l}\text { 9. Carteira escolar } \\
\text { portátil e econômica }\end{array}$ & $\begin{array}{c}\text { CORREIA \& CIA. } \\
(U)\end{array}$ & $\begin{array}{c}\text { Brasil, Juiz de Fora } \\
\text { - MG }\end{array}$ & $\begin{array}{l}\text { Jules Géraud \& } \\
\text { Leclerc (PROC) (U) }\end{array}$ & $\begin{array}{l}\text { Rio de Janeiro, } \\
17 / 11 / 1897\end{array}$ & 3478 & $\begin{array}{c}\text { Patente } 2423 \\
\text { Decreto } \\
25 / 11 / 1897\end{array}$ \\
\hline $\begin{array}{l}\text { 10. Banco escolar } \\
\text { Paulista }\end{array}$ & $\begin{array}{l}\text { BRENNE, Rudolf } \\
(\mathrm{F})\end{array}$ & $\begin{array}{c}\text { Brasil, São Paulo } \\
\text { - SP }\end{array}$ & $\begin{array}{l}\text { Jules Géraud \& } \\
\text { Leclerc (PROC) (U) }\end{array}$ & $\begin{array}{l}\text { Rio de Janeiro, } \\
07 / 04 / 1899 \\
\end{array}$ & 4017 & 2808 \\
\hline $\begin{array}{c}\text { 11. Três bancos- } \\
\text {-carteiras escolares } \\
\text { denominados Muni- } \\
\text { cipal, República e } \\
\text { Estrela }\end{array}$ & $\begin{array}{l}\text { SILVA, João de } \\
\text { Castro Lima e (F) }\end{array}$ & $\begin{array}{l}\text { Brasil, Rio de } \\
\text { Janeiro - RJ }\end{array}$ & $\begin{array}{l}\text { SILVA, João de } \\
\text { Castro Lima e (F) }\end{array}$ & $\begin{array}{l}\text { Rio de Janeiro, } \\
13 / 11 / 1900\end{array}$ & $?$ & 3226 \\
\hline $\begin{array}{l}\text { 12. Melhoramento } \\
\text { na invenção que faz } \\
\text { objeto da Patente } \\
\text { número 3226-Ban- } \\
\text { cos-Carteiras } \\
\text { Escolares }\end{array}$ & $\begin{array}{l}\text { SILVA, João de } \\
\text { Castro Lima e (F) }\end{array}$ & $\begin{array}{l}\text { Brasil, Rio de } \\
\text { Janeiro - RJ }\end{array}$ & $\begin{array}{l}\text { SILVA, João de } \\
\text { Castro Lima e (F) }\end{array}$ & $\begin{array}{l}\text { Rio de Janeiro, } \\
30 / 09 / 1901\end{array}$ & ? & 3226 BIS \\
\hline
\end{tabular}




\begin{tabular}{|c|c|c|c|c|c|c|}
\hline DESCRIÇÃO & AUTOR & DOMICÍlIO & REQUERENTE & $\begin{array}{l}\text { RELATÓRIO/ } \\
\text { ANO }\end{array}$ & REGISTRO & PATENTE \\
\hline $\begin{array}{l}\text { 13. Banco-carteira } \\
\text { para uso escolar }\end{array}$ & $\begin{array}{c}\text { CARVALHO, João } \\
\text { Paulo Batista } \\
\text { de (F) }\end{array}$ & $\begin{array}{c}\text { Brasil, Rio de } \\
\text { Janeiro - RJ }\end{array}$ & $\begin{array}{c}\text { CARVALHO, João } \\
\text { Paulo Batista } \\
\text { de (F) }\end{array}$ & $\begin{array}{l}\text { Rio de Janeiro, } \\
\text { 06/10/1896; } \\
\text { Rio de Janeiro, } \\
20 / 04 / 1900\end{array}$ & 4450 & 3080 \\
\hline $\begin{array}{l}\text { 14. Banco-carteira } \\
\text { escolar aperfei- } \\
\text { çoado }\end{array}$ & $\begin{array}{c}\text { PAGLIARO, Fran- } \\
\text { cesco (F) } \\
\text { SANTORO, } \\
\text { Giuseppe (F) }\end{array}$ & $\begin{array}{c}\text { Brasil, Rio de } \\
\text { Janeiro - RJ }\end{array}$ & $\begin{array}{l}\text { Jules Géraud, } \\
\text { Leclerc \& Cia. (U) }\end{array}$ & $\begin{array}{l}\text { Rio de Janeiro, } \\
26 / 11 / 1907\end{array}$ & 7580 & 5223 \\
\hline $\begin{array}{l}\text { 15. Móvel deno- } \\
\text { minado Carteira } \\
\text { Universal }\end{array}$ & $\begin{array}{c}\text { CARVALHO, } \\
\text { Bernardo Pereira } \\
\text { de }(F)\end{array}$ & $\begin{array}{c}\text { Brasil, Rio de } \\
\text { Janeiro - RJ }\end{array}$ & $\begin{array}{c}\text { CARVALHO, } \\
\text { Bernardo Pereira } \\
\text { de (F); } \\
\text { Administr.(s) } \\
\text { COCHRANE, } \\
\text { Tomás Wallace } \\
\text { da Gama } \\
\text { VALDETARO, José } \\
\text { Crispiniano }\end{array}$ & $\begin{array}{l}\text { Rio de Janeiro, } \\
23 / 10 / 1897\end{array}$ & 3457 & $\begin{array}{c}\text { Observações } \\
\text { Consta do } \\
\text { envelope: "Aberto } \\
\text { e encerrado para } \\
\text { serem reformados } \\
\text { os desenhos. } \\
24 / 1 / 1898 \text {. Th. } \\
\text { Cochrane. J.C. } \\
\text { Valdetaro. Ber- } \\
\text { nardo Pereira de } \\
\text { Carvalho". }\end{array}$ \\
\hline $\begin{array}{l}\text { 16. Banco-carteira } \\
\text { aperfeiçoada }\end{array}$ & $\begin{array}{c}\text { PAGLIARO, Fran- } \\
\text { cesco (F) } \\
\text { SANTORO, } \\
\text { Giuseppe (F) }\end{array}$ & $\begin{array}{c}\text { Brasil, Rio de } \\
\text { Janeiro - RJ }\end{array}$ & $\begin{array}{l}\text { Jules Géraud, } \\
\text { Leclerc \& Cia. (U) }\end{array}$ & $\begin{array}{l}\text { Rio de Janeiro, } \\
28 / 09 / 1907\end{array}$ & 7457 & $?$ \\
\hline $\begin{array}{l}\text { 17. Banco-carteira } \\
\text { escolar denominado } \\
\text { Sistema Cristóvão }\end{array}$ & $\begin{array}{c}\text { AULER, Cristóvão } \\
\text { William (F) }\end{array}$ & & $\begin{array}{c}\text { AULER, Cristóvão } \\
\text { William (F) }\end{array}$ & $\begin{array}{l}\text { Rio de Janeiro, } \\
17 / 11 / 1894\end{array}$ & 2545 & ? \\
\hline $\begin{array}{l}\text { 18. Pé aperfei- } \\
\text { çoado para bancos } \\
\text { de carteiras escola- } \\
\text { res e outros bancos } \\
\text { de assento levadiço }\end{array}$ & AULER E CIA. (U) & $\begin{array}{c}\text { Brasil, Rio de } \\
\text { Janeiro - RJ }\end{array}$ & $\begin{array}{l}\text { Jules Géraud, } \\
\text { Leclerc \& Cia. (U) }\end{array}$ & $\begin{array}{l}\text { Rio de Janeiro, } \\
\text { 02/05/1903 }\end{array}$ & 5579 & ? \\
\hline $\begin{array}{l}\text { 19. Melhoramento } \\
\text { introduzido na } \\
\text { invenção privile- } \\
\text { giada pela Patente } \\
\text { n. } 2172 \text { (banco- } \\
\text {-carteira) }\end{array}$ & $\begin{array}{l}\text { NOGUEIRA, } \\
\text { Adriano Júlio dos } \\
\text { Santos (F) }\end{array}$ & $\begin{array}{c}\text { Brasil, Rio de } \\
\text { Janeiro - RJ }\end{array}$ & $\begin{array}{l}\text { Jules Géraud \& } \\
\text { Leclerc (Proc) (U) }\end{array}$ & $\begin{array}{l}\text { Rio de Janeiro, } \\
25 / 11 / 1898\end{array}$ & & 2172 \\
\hline $\begin{array}{l}\text { 20. Pé aperfei- } \\
\text { çoado para bancos } \\
\text { de carteiras escola- } \\
\text { res e outros bancos } \\
\text { de assento levadiço }\end{array}$ & AULER E CIA. (U) & $\begin{array}{c}\text { Brasil, Rio de } \\
\text { Janeiro - RJ }\end{array}$ & $\begin{array}{l}\text { Jules Géraud, } \\
\text { Leclerc \& Cia. (U) }\end{array}$ & $\begin{array}{l}\text { Rio de Janeiro, } \\
30 / 05 / 1903\end{array}$ & 5610 & \\
\hline
\end{tabular}

Fonte: Elaboração da autora a partir da Coleção Privilégios Industriais (PI): inventário analítico - conteúdo por notação / Equipe de documentos do Executivo e Legislativo. $2^{a}$. ed. rev. Rio de Janeiro: o Arquivo, 2013. Arquivo Nacional (Brasil). Coordenação de documentos Escritos. Equipe de documentos do Executivo e Legislativo. 
realizou. Maria Helena Camara Bastos afirma que, na segunda metade do século XIX, - "Estado brasileiro faz da educação um grande espetáculo, promove conferências - populares, públicas, literárias, pedagógicas ou de professores; organiza congressos, exposições pedagógicas, museus escolares e pedagógicos" ${ }^{\prime \prime 7}$.

Dentre os eventos ocorridos no Brasil, selecionei a Primeira Exposição Pedagógica do Rio de Janeiro de 188398.

[O] Imperador Pedro II convoca um congresso para tratar de questões que interessem à instrução pública na corte e nas províncias [...] A presidência do Congresso da Instrução ficou a cargo do Príncipe Conde D'Eu [...] em 13 de janeiro de 1883, o Conde D'Eu propôs a realização de uma Exposição Pedagógica ${ }^{99}$

De acordo com Kuhlmann Jr. ${ }^{100}$, as "instituições de educação popular foram destaque durante a Exposição Industrial no Rio de Janeiro, em 1881, que contou com uma seção da Instrução Pública". $\bigcirc$ autor ainda acrescenta que "a Exposição Industrial de 1881 foi o primeiro impulso para a realização da Exposição Pedagógica, em 1883, que também pretendia abrigar o Congresso de Instrução" ${ }^{\prime 01}$. O congresso não foi realizado ${ }^{102}$, mas os pareceres elaborados acerca dos objetos expostos são documentos férteis para identificação dos países participantes e das percepções dos pareceristas acerca da relevância de certos materiais para a escola moderna.

No âmbito dessa exposição, o Relatório do Júri sobre o Grupo 3 Mobiliário Escolar traz uma contribuição importante a este trabalho por, pelo menos, cinco razões: 1) Permite conhecer as características que o júri ${ }^{103}$ considerou essenciais na mobília escolar; 2) Expõe detalhes da mobília escolar apresentada pelos países participantes (Bélgica, França, Inglaterra, Alemanha, Suécia, Estados Unidos), já que o júri estudou os modelos de carteira, tomando como referência as características previamente estabelecidas; 3) Destaca os colégios particulares brasileiros que procuram "caminhar em paralelo com estes melhoramentos" na carteira; 4) Explicita os critérios segundos os quais foram premiados os expositores; 5) Dá a conhecer os expositores que obtiveram diplomas e menções honrosas.

Na Primeira Exposição Pedagógica do Rio de Janeiro, os jurados definiram, primeiramente, as cinco características essenciais da mobília escolar:

$1^{\circ}$. Proporcionalidade das dimensões dos bancos e mesas com a estatura dos alumnos; $2^{\circ}$. Jogo, a que as peças destes moveis estão sujeitos; $3^{\circ}$. Numero de logares em cada móvel; $4^{\circ}$. Simplicidade da sua construção e conservação; $5^{\circ}$. Natureza da sua pintura ${ }^{104}$.

Segundo o júri, dentre todos, "o primeiro caracteristico é o mais importante, porque affecta uma propriedade hygienica dos moveis" ${ }^{105}$. A segunda característica "refere-se á mobilidade ou fixidez das peças de que se compõe um banco-carteira"106. A comissão opta pela fixidez das peças justificando que "a experiência demonstra que, sempre que o alumno tem na mobília á sua disposição peças moveis, com que possa distrair-se ou brincar, os estragos são frequentes e a conservação dispendiosa" ${ }^{107}$.
97. Cf. Maria Helena Camara Bastos (2005, p. 116).

98. "Inaugurada em 29 de julho de 1883 , contou com a participação de vários países: Bélgica; Itália; França; EUA; Uruguai, Chile; Argentina; Áustria; Espanha; Portugal; Suíça; Holanda; Alemanha; Inglaterra; Suécia; e os Estabelecimentos dos Irmãos da Doutrina Cristã", cf. Maria Helena Camara Bastos (2002, p. 263).

99. Cf. Maria Helena Camara Bastos (2005, p. 121).

100. Cf. Moysés Kuhlmann Jr. (2005, p. 73)

101. Cf. Moysés Kuhlmann Jr. (2005, p. 73)

102. Sobre os motivos da não realização do congresso, ver Therezinha Collichio (1987, p. 7).

103. "Os referidos grupos e comissões ficaram organizados pela seguinte forma: Mobília Escolar - Dr. A. de Paula Freitas, Dr. João Pedro de Aquino, Dr. Manoel Velloso Paranhos Pederneiras", cf. Rio de Janeiro (1884, p. 55).

104. Cf. Rio de Janeiro (1883, p. 25).

105. Cf. Rio de Janeiro (1883, p. 26).

106. Cf. Rio de Janeiro (1883, p. 28).

107. Cf. Rio de Janeiro (1883, p. 29). 
108. Cf. Rio de Janeiro (1883, p. 29).

109. Cf. Rio de Janeiro (1883, p. 29).

110. Cf. Rio de Janeiro (1883, p. 29).

111. Cf. Rio de Janeiro (1883, p. 30).

112. Cf. Rio de Janeiro (1883, p. 30).
Quanto ao número de lugares da carteira, a comissão estabelece que:

os bancos-carteiras de um so logar devem ser preferidos, ou pelo menos constituem um novo ideal para o qual se deve tender em questão de mobilia escolar, e sempre que algum motivo economico não determine o contrario. $\bigcirc$ alumno esta ao abrigo de uma infinidade de perturbações, como sejam: a conversa, a indisciplina, as distracções, e mesmo, sem parecer exageração, a immoralidade; elle tem por assim dizer, o seu pequeno dominio para si tão somente, e pelo qual é responsavel. Mas, como o obstaculo economico é de muito peso, usa-se frequentemente dos moveis de dous logares; com effeito, os de um logar tomam mais espaço na sala que os de dous; exigem portanto uma despeza maior de construcção do edificio relativamente ao mesmo numero de alumnos; custam mais caros, porque dous bancos-carteiras separados exigem mais mão de obra e material que um so com os dous logares ${ }^{108}$.

A simplicidade é exigida em oposição à "solução da phantasia, baseada muitas vezes em combinações arbitrarias, porque d'ahi provêm disposições na mobília, que a tornam defeituosa ou imprestável para os fins a que se destina"109.

Vê-se que o preço da fabricação, conservação/manutenção do mobiliário não é desprezível para o Estado e seus agentes, diante de um item cujo valor, em quantidade, é elevado. Por isso, a comissão vai defender que "o essencial em um móvelescolar é que elle seja solido, simples e firme, para não encarecer o fabrico, nem a conservação"110.

Se há um aspecto que o Estado valoriza na carteira, por questões econômicas, é a sua durabilidade. $\bigcirc$ alto investimento deve ser compensado ao longo do tempo. Ele não pode se repetir a cada ano ou mesmo a cada década. Não localizei relatórios do júri de outras exposições universais ou pedagógicas que permitissem analisar o lugar conferido à durabilidade da carteira. Para a comissão do grupo Mobília Escolar, da Exposição do Rio de Janeiro, a durabilidade era uma característica essencial à carteira. Talvez porque em um país no qual muitas escolas não dispunham sequer de mobília, conservar por longo tempo aquelas que já existiam era fundamental.

A conservação dizia respeito ao móvel como um todo e às suas partes. Era preciso evitar a constante renovação das peças. $\bigcirc$ uso do ferro fundido, tão disseminado no período, é desaconselhado pela comissão, também por uma questão econômica - a manutenção do mobiliário. De acordo com o júri, "[...] o uso do ferro não é sempre conveniente, mórmente o ferro fundido, que é muito sujeito a quebrar-se com qualquer choque $[\ldots]^{\prime \prime 111}$. No entanto, países como Bélgica, Estados Unidos, Inglaterra e Alemanha apresentaram carteiras fabricadas com ferro fundido. A dificuldade das reparações fez com que em alguns países o uso do ferro fundido fosse rejeitado.

Tal dificuldade não se daria com as carteiras de madeira, pois

Não ha villa ou aldeia, que não disponha de um carpinteiro ou marceneiro, que seja capaz de reparar um banco ou uma mesa de madeira; mas o mesmo não acontece com o ferro fundido. A necessidade de reparações é portanto uma das previsões, que não se póde deixar de tomar em consideração, pelo menos para as escolas ruraes, que nem sempre dispõem nas suas proximidades de officinas para aquelles trabalhos ${ }^{12}$. 
A razão é puramente econômica, já que o uso das carteiras com peças de ferro fundido não é desaconselhado nas escolas urbanas "que disponham dos recursos para as reparações de que venham a carecer"113. Relacionada à conservação, estava a facilidade para a limpeza. Para tanto, a comissão recomenda que a pintura seja a óleo fervido ou que as carteiras sejam envernizadas.

Depois de estabelecidos os critérios de julgamento das carteiras, a comissão passa ao estudo dos modelos expostos pelos diversos países.

A Bélgica apresentou cinco bancos-carteiras inventados pelo arquiteto Blandot-Grayet para escolas de meninas. Os bancos-carteiras eram envernizados, "inteiramente de madeira, com dous logares cada móvel peças fixas e proporcionaes aos alumnos que os devem occupar ${ }^{\prime \prime 14}$. Havia também um modelo para escolas de meninos, dois modelos para meninos e meninas das escolas normais.

Cabe aqui, a respeito destes moveis, uma observação importante. A caixa da carteira a principio era móvel, escorregando horizontalmente afim de augmentar ou diminuir a sua distancia ao banco, de sorte a permittir ao alumno ficar de pé entre o banco e a carteira; mas, como esta disposição mostrou graves inconvenientes, segundo refere Narjoux, tratou-se logo de substituir a mesa móvel por outra fixa; provando-se assim a conveniência da fixidez das peças da mobília escolar ${ }^{115}$.

Os móveis expostos agradaram ao júri brasileiro e atenderam às características exigidas, pois o Ministério da Instrução Pública da Bélgica recebeu diploma de honra "por ter sido a Bélgica o país que mais sobressaiu na Exposição - Pelos especimens de mobilias escolares"116. Além dos bancos-carteiras, o país exibiu mesa e cadeira de professor, escabelo ${ }^{17}$ (único país a expor esse objeto), armário-biblioteca, cabides, lavatório e pedras (tableaux).

Da França, duas fábricas enviaram seus produtos: Crédit des écoles, Walcker \& Cia. e Garcet \& Nisius. A primeira recebeu diploma de honra "Pela mobilia escolar fabricada de conformidade com as disposições regulamentares do governo francês, de 17 de junho de 1880"118. $\bigcirc$ material de fabricação da carteira era madeira pintada de cores escuras. Tinha dois lugares, bancos e peças fixas "com inclinação, e uma estante para livros. A distancia da carteira ao banco é nulla"119.

Garcet e Nisius, construtores e editores de Paris, apresentaram carteiras de dois lugares, com tampo móvel, assento fixo, distância nula, polido e pintado de escuro. No Catálogo Mobilier Scolaire et Materiel d'Enseignement de Garcet e Nisius, publicado em 1882, há dois modelos de carteiras que poderiam ser fabricadas com tampo móvel. Um deles, talvez fosse o mesmo móvel exposto um ano depois na Exposição Pedagógica do Rio de Janeiro (figura 15).

$\bigcirc$ modelo para uso em escolas infantis e primárias custava 10 francs por assento. A carteira para dois alunos custaria 20 francs. Se a mesma carteira for solicitada com tampo articulado, o valor passaria a ser 28 francs. A carteira para Escola Normal também poderia ser fabricada com tampo articulado (figura 16).
113. Cf. Rio de Janeiro (1883, p. 30).

114. Cf. Rio de Janeiro (1883, p. 31).

115. Cf. Rio de Janeiro (1883, p. 32). O arquiteto francês Felix Narjoux atuou durante o exercício de Jules Ferry como Ministro da Instrução Pública. Jules Ferry sancionou o Regulamento para a construcção e mobiliamento das casas de escola, em 17 de julho de 1880 Tomando esse documento como referência, Narjoux escreveu regulamentos para a construção e o mobiliamento de escolas na França e Inglaterra. Ele era especialista em mobiliário escolar. Tornou-se autoridade no assunto, mesmo fora da França, a ponto de carteiras escolares na Bélgica serem modificadas devido às instruções dele.

116. Cf. Rio de Janeiro (1883, p. 60-61).

117. Trata-se de um pequeno banco que serve de apoio aos pés.

118. Cf. Rio de Janeiro (1883, p. 70).

119. Cf. Rio de Janeiro (1883, p. 33). 
120. As exposições locais ocorriam em uma cidade ou microrregião, via de regra, como eventos preparatórios para as exposições nacionais, que, por sua vez, envolviam um país e tinham um caráter preparatório para as exposições mundiais ou universais.

121. Cf. Rio de Janeiro (1883, p. 76).

122. Cf. Rio de Janeiro (1883, p. 76).

123. Cf. Rio de Janeiro (1883, p. 37).
Diferente da anterior, era fabricada com pés de ferro e custava 5 francs a mais por assento. Com tampo articulado, a carteira para dois alunos seria 38 francs (figura 17).

O tampo móvel ou articulado acrescia 4 francs ao preço total da carteira. Cada dispositivo ou tecnologia empregada fazia a mercadoria ficar mais cara e acessível a poucas escolas. Garcet \& Nisius recebeu menção honrosa na Exposição de Paris, em 1878, e medalhas de prata, sendo duas em 1880 (Melun e Le Mans) e uma em 1881 (Tours), provavelmente, exposições locais ou nacionais ${ }^{120 .}$

Para convencer o leitor e/ou cliente que as carteiras produzidas eram de acordo com o Regulamento de Jules Ferry, os construtores destacavam nas páginas iniciais do catálogo artigos do Règlement Ministériel du 17 juin 1880. 0 Art. 90, por exemplo, estabelecia que a carteira deveria ser de um ou dois lugares; o art. 96 prescrevia que a distância entre o assento e a superfície de trabalho deveria ser nula. $\bigcirc$ Regulamento de 1880 determinava, ainda, um espaço abaixo do tampo da mesa para guardar os livros (art.97) e um tinteiro móvel de vidro ou porcelana, adaptado à mesa e colocado à direita do aluno (art.98).

Atender a cada um desses quesitos tornava o custo final do produto mais elevado para o cliente, o que poderia transformar algumas carteiras, premiadas por satisfazer diversas exigências higiênicas, em objeto de contemplação nas exposições e não em objeto da escola. No Rio de Janeiro, Garcet \& Nisius recebeu diploma de honra "pelos moveis que expos para escolas maternaes, fabricados segundo as prescrições regulamentares do governo francês, de 2 de agosto de $1881^{\prime \prime 21}$.

Inglaterra foi o país que enviou maior quantidade de móveis escolares. Da fábrica inglesa Geo, M. Hammer \& Cia, fundada em 1858, vieram para a exposição um modelo de banco-carteira do sistema Moss, um modelo Phoenix (patenteado), um modelo Moss para jardim de infância, um banco-carteira com estante para livros, um modelo para meninas, um modelo de caixa dupla, a carteira individual Lovise, a carteira conversível Osborne, uma mesa pedestal para professor (combinação de mesa e armário com gavetas), uma carteiras com armário para professor, uma carteira para adjunto contendo um armário com porta, bancos de escola com pés de ferro fundido, tinteiros e tampos, bule de tinta, porta-canetas, ganchos e cavaletes para mapas, cavaletes para pedras, pedras móveis e fixas.

Essa casa comercial de Londres recebeu diploma de honra "pela variedade de modelos de moveis que expoz para escolas primarias e da infância, professores, adjuntos, e vários accessorios de uma classe, e nos quaes se acham attendidos vários preceitos de hygiene" 122 .

Outra fábrica de Londres, H\& G. Edwards, fundada em 1823, expôs dois modelos de carteira, mesa para professor e adjunto, banco conversível e banco para igreja. "Foram tambem expostos - cavalletes para desenho, e para pedras fixas, pedras moveis, tinteiros e porta-inteiros; mas a commissão não os descreverá, por serem semelhantes aos da fabrica Hammer \& Cia"123. 


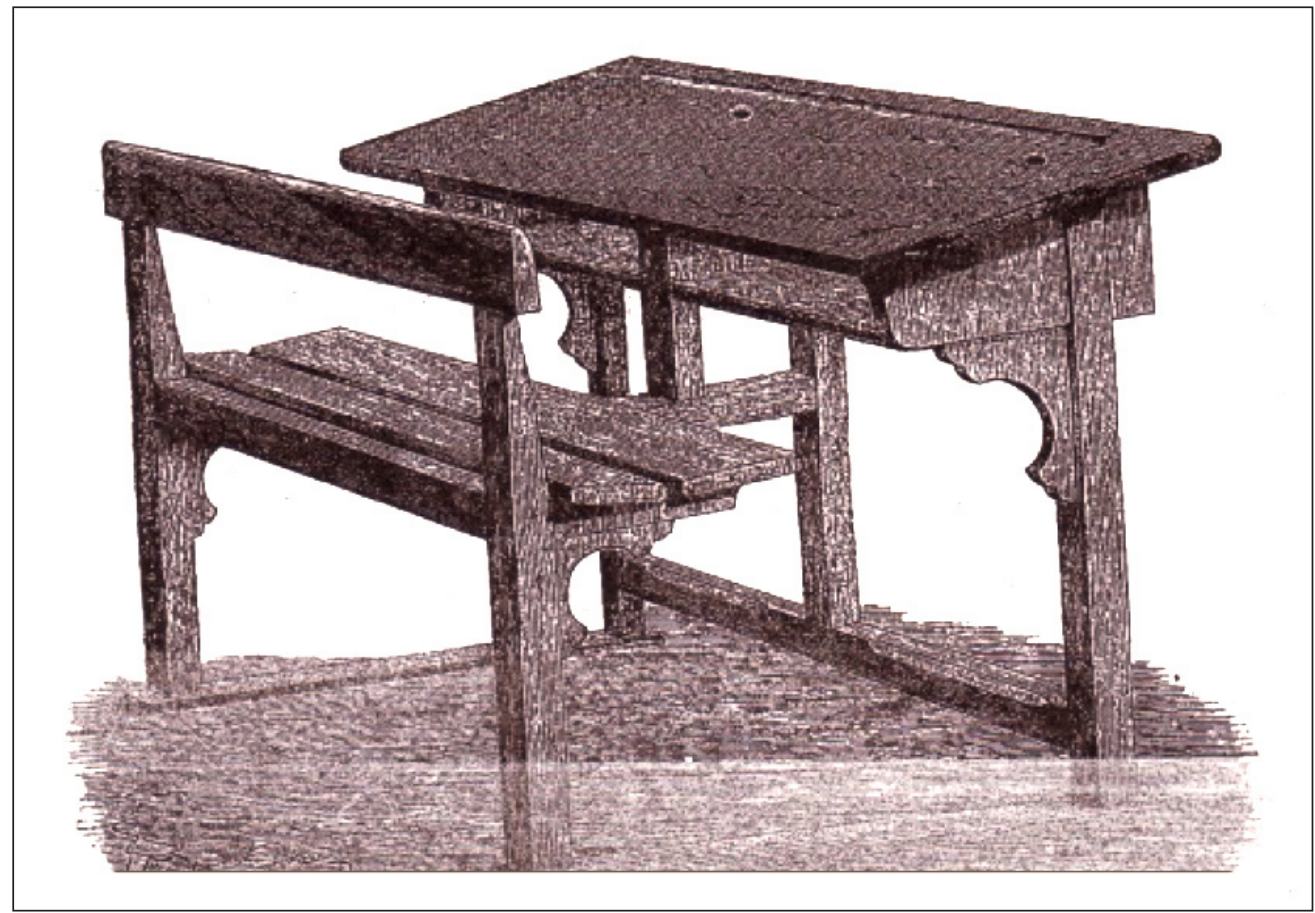

Figura 15 - Modelo da cidade de Paris. Imagem extraída do catálogo Mobilier Scolaire et Matériel d'Enseignement, de P. Garcet e Nisius (1882, p. 6). Bibliothèque Nationale de France.

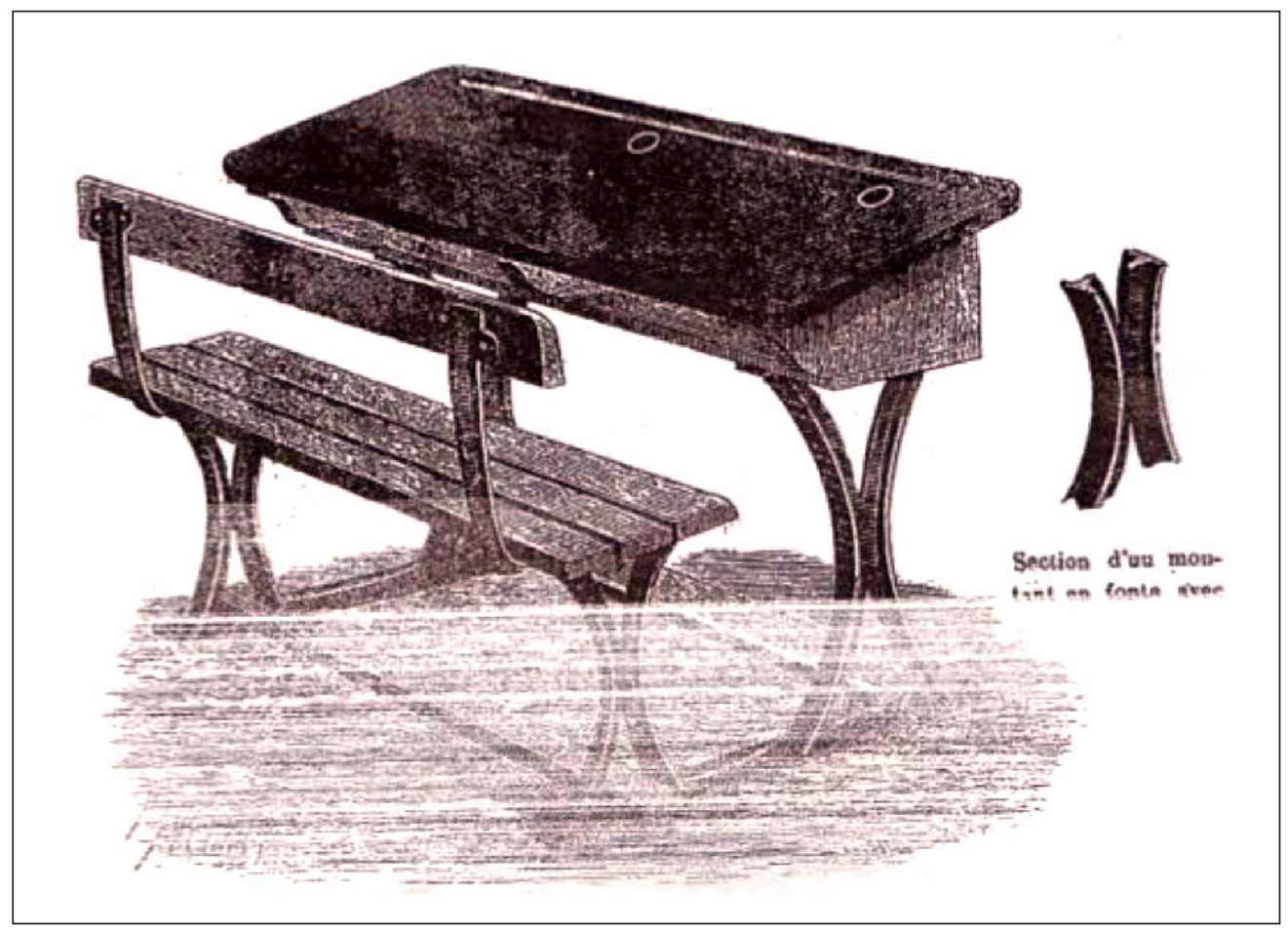

Figura 16 - Carteira para Escola Normal. Imagem extraída do catálogo Mobilier Scolaire et Matériel d'Enseignement, de P. Garcet e Nisius (1882, p. 9). Bibliothèque Nationale de France. 
124. Cf. Rio de Janeiro (1883, p. 37).

125. Cf. Rio de Janeiro (1883, p. 77).

126. Cf. Rio de Janeiro (1883, p. 38).

127. Cf. Rio de Janeiro (1883, p. 39).

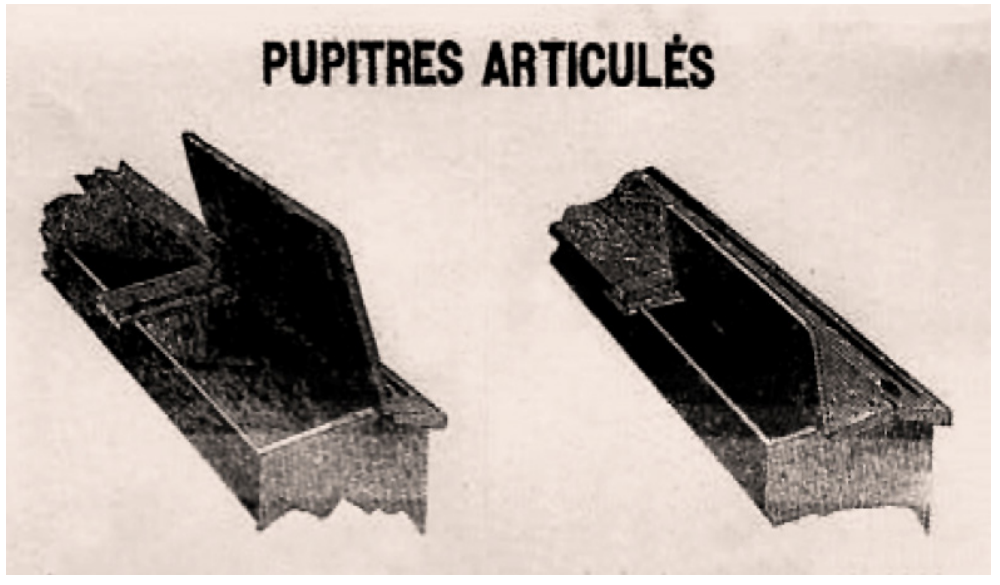

Figura 17 - Tampo articulado. Imagem extraída do catálogo Mobilier Scolaire et Matériel d'Enseignement, de P. Garcet e Nisius (1882, p. 11 ). Bibliothèque Nationale de France.

Na diversidade de produtos ingleses havia também objetos de lavatórios e privadas das escolas primárias.

O lavatorio é uma peça com bacias de louça, que se póde collocar junto a uma parede qualquer; é munido de torneiras para agua e de esgoto para cada bacia.

O urinario é uma peça de ferro, barro cozido e lousa, que póde ser completamente armada e desarmada, e é feita de fórma a occupar uma pequena area com 3 compartimentos.

As latrinas são preparadas para serem completamente inodoras por um modo especial em que empregam os grandes pactos d'agua. Infelizmente a commissão expositora não recebeu todas as peças destes apparelhos ${ }^{124}$

A Casa H \& G Edwards recebeu diploma de honra "pela mobilia que expoz para alumnos, professores e adjuntos; pelos quadros de historia natural" 125 , este último sem apreciação pela comissão do grupo 3, Mobília Escolar, por não comporem a categoria.

A comissão se delongou na análise da mobília americana. Parecia haver uma expectativa da comissão quanto às carteiras enviadas pelos Estados Unidos. De acordo com os avaliadores, a exposição americana de mobília escolar estava incompleta, pois

não se póde, pelo que foi exposto, fazer ideia da variedade immensa que os Estados-Unidos têm imaginado em assumpto de mobilia com apropriação ás escolas de differentes categorias, que alli existem, e é isto tanto mais de lastimar, quanto é sabido que foi aquella poderosa e colossal nação, que inaugurou, com os conselhos de Bernard, a reforma no material escolar ${ }^{126}$.

Há duas características distintivas da mobília americana que, no entendimento da comissão, já eram conhecidas do Brasil: "o emprego do ferro fundido em toda a sua armação, entrando a madeira para formar o tampo da mesa, a pequena estante sobre a mesa, e o assento e encosto dos bancos" e "o encosto do banco de um alumno forma as costas da carteira de outro"127. 
relatório da comissão é tão favorável à mobília americana a ponto de afirmar que ela vai "além dos limites que a hygiene prescreve"128. Para a comissão, isso se revela nos detalhes dos móveis.

Incontestavelmente toda a mobília escolar americana é feita com um cuidado particular, desde o banco-carteira até a pedra ou quadro ardosiado e a própria esponja para esta pedra: acha-se no menor detalhe a applicação do útil e do confortável [...] Os educadores, nos Estados Unidos querem, conforme diz Braun, que o alumno se ache na escola tão commodamente instalado, tão independente, como na sua própria casa, como si elle se sentisse realmente em sua residência ${ }^{129}$.

conforto também é proporcionado pela carteira individual - "ultima palavra do progresso em moveis escolares do systema americano"130. Apesar do predomínio americano no mercado de carteira escolar, somente uma empresa participou da Exposição Pedagógica do Rio de Janeiro, em 1883.

A Casa Baker, Pratt \& Comp., de Nova York, expôs três modelos: 1) The National folding-seat desk, uma carteira individual fabricada em cinco categorias. A n. 1, para alunos entre 14 e 20 anos; a n.2, para alunos entre 12 e 14 anos; a n.3, para alunos entre 10 e 12 anos; a n.4, para alunos entre 8 e 10 anos; a n.5, para alunos entre 4 e 8 anos. 2) The Triumph School Desk, premiada na exposição de Paris de 1878, "tem a vantagem de uma armação de ferro com madeira, a mais forte, compacta e duradoura, que se tenha até o presente imaginado"131. 3) The new folding-lid study-desk, diferencia-se das demais por ter o tampo móvel, "prestando-se assim á leitura"132. A Casa recebeu premiação no Rio de Janeiro "pela engenhosa mobilia que expoz, denominada - The National folding-seat desk"133.

A Suécia expôs um único modelo, classificado pela comissão como "digno de nota", por três razões. Era feito todo em madeira, de um só lugar e atendia às prescrições higiênicas a respeito da distância entre o banco e a carteira. Como todos os outros países, a Suécia recebeu menção honrosa. Somente a Alemanha não recebeu nenhuma premiação, apesar dos quatro modelos de carteira exibidos. De acordo com a comissão

toda essa mobília é composta de differentes peças moveis (...) [o que gera dois inconvenientes:] (...) motivos de distracção, e póde ser causa de magoar os dedos de um dos alumnos que ocuppam o móvel; os bancos são também moveis, e recuam com qualquer impulso, mas são mais do que as carteiras, motivos de distracção para os alumnos como por exemplo, pondo-os em movimento só para produzirem o choque de encontro ás travessas do movel ${ }^{134}$.

A crítica da comissão recaiu sobre o excesso de movimento das peças. Dentre os expositores brasileiros, somente o Colégio Abílio não recebeu menção honrosa. $\bigcirc$ referido colégio expôs carteiras americanas singulares. No parecer da comissão, "o sistema mobiliar deste importante colégio é todo americano, e os seus diretores não cessam de adquirir e realizar todos os melhoramentos que a experiência aconselha"135.
128. Cf. Rio de Janeiro (1883, p. 39).

129. Cf. Rio de Janeiro (1883, p. 39).

130. Cf. Rio de Janeiro (1883, p. 39).

131. Cf. Rio de Janeiro (1883, p. 40).

132. Cf. Rio de Janeiro (1883, p. 40).

133. Cf. Rio de Janeiro (1883, p. 76).

134. Cf. Rio de Janeiro (1883, p. 38).

135. Cf. Rio de Janeiro (1883, p. 41) 
136. Cf. Rio de Janeiro (1883, p. 89).

137. Conforme o Almanak Administrativo, Mercantil e Industrial do Rio de Janeiro, do ano de 1898 (p. 1498), tratava-se de uma fábrica de móveis a vapor.

138. Cf. Rio de Janeiro (1883, p. 44).

139. Cf. Rio de Janeiro (1883, p. 44).

140. Cf. Rio de Janeiro (1883, p. 77).

141. Cf. Rio de Janeiro (1883, p. 43).

142. Cf. Rio de Janeiro (1883, p. 44).

143. Cf. Rio de Janeiro (1883, p. 41).

144. Cf. Rio de Janeiro (1883, p. 89).

145. Cf. Josette Peyranne (2001, p. 136).
Alguns brasileiros expuseram carteiras de fabricação própria, outros exibiram carteiras adaptadas de modelos estrangeiros. Ainda houve quem apresentasse os móveis utilizados em suas escolas e colégios, porém fabricados por outras empresas.

Duas professoras receberam menção honrosa pelo móvel escolar que mandaram construir - D. Amalia Justa dos Passos Coelho e Silva e D. Octavia Emilia Coelho e Silva. Um professor, Gustavo José Alberto, foi premiado "pelos dois moveis conversíveis que fez construir" ${ }^{\prime \prime 36}$.

As fábricas de móveis que compareceram foram: Fabrica de Moveis de Manoel Monteiro Bentim \& Irmão ${ }^{137}$, cujo banco-carteira era de "muito luxo, perfeitamente trabalhado"138, mas não preenchia, do ponto de vista da comissão, as condições higiênicas do mobiliário escolar. O Dr. Carlos Augusto de Carvalho, ex-presidente da província do Paraná, tornou-se fabricante de móveis para as escolas públicas de Curitiba. Para a comissão, tratava-se de um homem ilustrado com vasto conhecimento, que iniciou e promoveu "a reforma no antiquado systema mobiliar"139 em uso no Paraná. Ele foi premiado "pelo banco-carteira de dois lugares" 140 . O móvel tinha as seguintes características:

O movel, que imaginou e fez executar, é de dous logares, de pinho, tenho a mesa e o banco moveis, de sorte a adaptal-os á estatura dos alumnos. Os dous bancos estão separados, e por isso no seu intervallo se colloca uma escarradeira.

A commissão conforme mostrou, é contraria á mobilidade das peças dos moveis escolares, salvo quando ellas tenham de prestar-se a certos fins especiaes. Não deixa, porém, de apreciar os louváveis esforços do expositor em beneficio da instrucção primaria ${ }^{141}$.

Um terceiro fabricante era Dulcerio José Machado, conhecido pela construção de bancos-carteira "segundo o systema americano e adoptados nas escolas publicas da Provincia do Rio de Janeiro, conforme annuncia o seu constructor"142.

Atentar para a atividade econômica desenvolvida pelos expositores da Exposição Pedagógica do Rio de Janeiro, de 1883 põe em evidência perfis e peculiaridades dos sujeitos interessados e envolvidos no comércio de carteira escolar. Poucos eram os professores e professoras: em número de três; três os industriais com fabricação própria de móveis escolares; e entre os importadores de objetos escolares estavam duas livrarias - Livraria Faro \& Lino e a Livraria Alves \& $C^{i a}$.

A Livraria Faro \& Lino, por exemplo, expôs "varios moveis escolares da fabrica Hachette \& Comp. de Paris, como sejam: 1 banco-carteira sistema Cardot" 143, mesa Hachette para desenhar, mesa do adjunto do professor, dentre outros. A casa recebeu premiação "pelos modelos de mobilia Hachette, Cardot, de Paris para jardins de infancia" 144. O modelo Cardot foi lançado na Exposição Universal de 1873, em Viena. "Este ex-prefeito do XX distrito de Paris propôs um mobiliário com mesa móvel e assento fixo" (figura 18)145.

A superfície de trabalho em posição elevada servia para desenhar; em posição semielevada, para colocar o livro de leitura; em posição rebatida, fechava os tinteiros. 

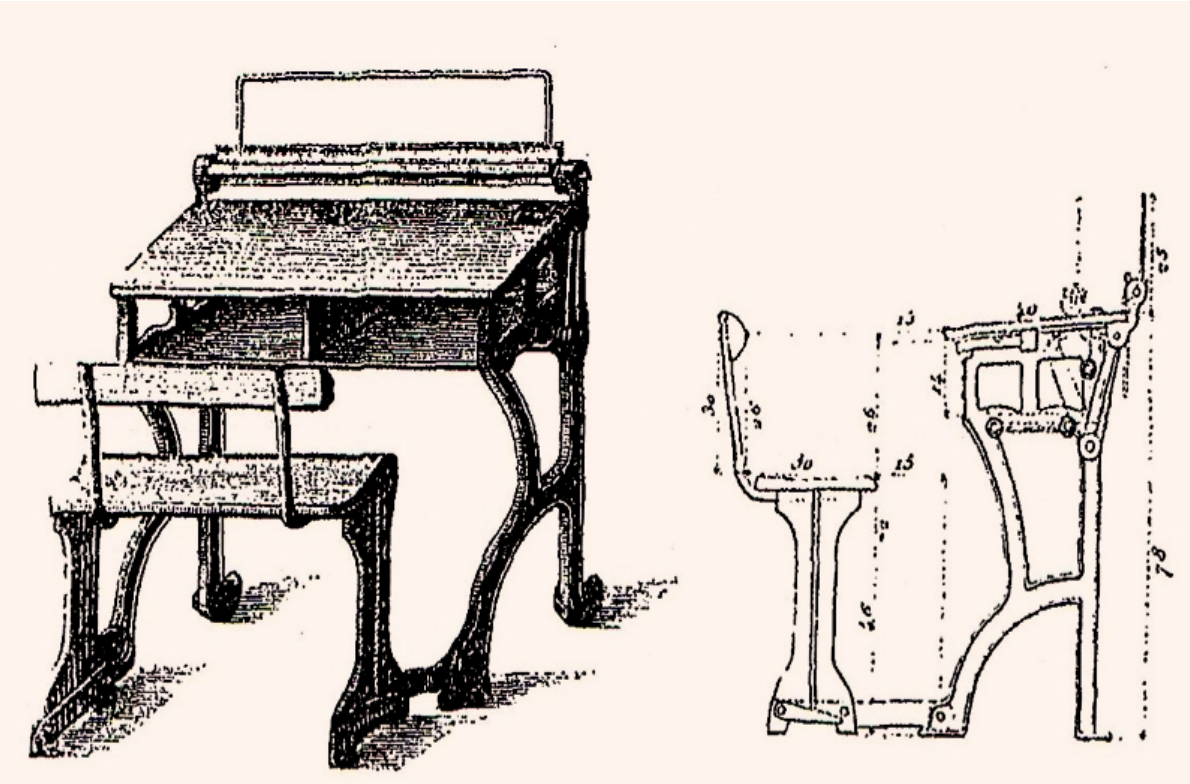

Figura 18 - Carteira Modelo Cardot proposto em Paris. Imagem extraída do livro de Josette Peyranne $(2001$, p. 136).

A Livraria Alves \& Ca, "este antigo e conhecido estabelecimento de livros classicos"146, apresentou outras carteiras em uso na França, conhecidas nas exposições universais. Eram os modelos de M. Bapterosses e "de M. André, constructor em Neuilly, e baseado em uma disposição, que já havia sido tentada por Mlle. Lecour e Cardot em 1873"147.

modelo Bapterosses foi o mais notável da Exposição Universal de 1873, em Viena. Segundo Peyranne ${ }^{148}$ em seu relatório, Buisson o qualificou como o teste mais satisfatório dos países europeus e o júri o premiou com o diploma de mérito (figura 19).

Como se vê, a mesa fixa é acompanhada de um banquinho regulável em altura. "Os pés da mesa e do banco são de ferro [...] $\bigcirc$ apoio para os pés é um patim de ferro montado sobre um eixo de suporte, ele desliza em um revestimento igualmente bloqueado para parafuso [...] Só o mestre possui a chave especial para regular o assento"149.

Entre os modelos de carteira reguláveis e adaptáveis a todos os tamanhos, destaca-se o modelo "apresentado por Bagnaux em sua conferência sobre o mobiliário da classe em 1878. Projetado por André, construtor de Neuilly, este modelo possui uma mesa fixa e um assento movel [...]" (figura 20)150.

Outra qualidade do modelo era o apoio para os pés que tinha a finalidade de evitar os problemas circulatórios ${ }^{151}$. É o próprio De Bagnaux que publica um resumo de sua conferência sobre o mobiliário escolar em 1878, na Revue Pedagogique de 1879, e afirma que "a carteira André, que é preferível
146. Cf. Rio de Janeiro (1883, p. 43).

147. Cf. Rio de Janeiro (1883, p. 43).

148. Ver Josette Peyranne (2001)

149. Cf. Josette Peyranne (2001, p. 136).

150. Cf. Josette Peyranne (2001, p. 165).

151. Ver Josette Peyranne (2001). 
152. Cf. De Bagnaux (1879, p.132).

153. Cf. Revue Pedagogique (1879, p. 44).

154. Cf. Rio de Janeiro (1883, p. 41).

155. Cf. Rio de Janeiro (1883, p. 41).

156. A esse respeito ver Diana Gonçalves Vidal (2006).

157. Cf. Rio de Janeiro (1883, p. 77).

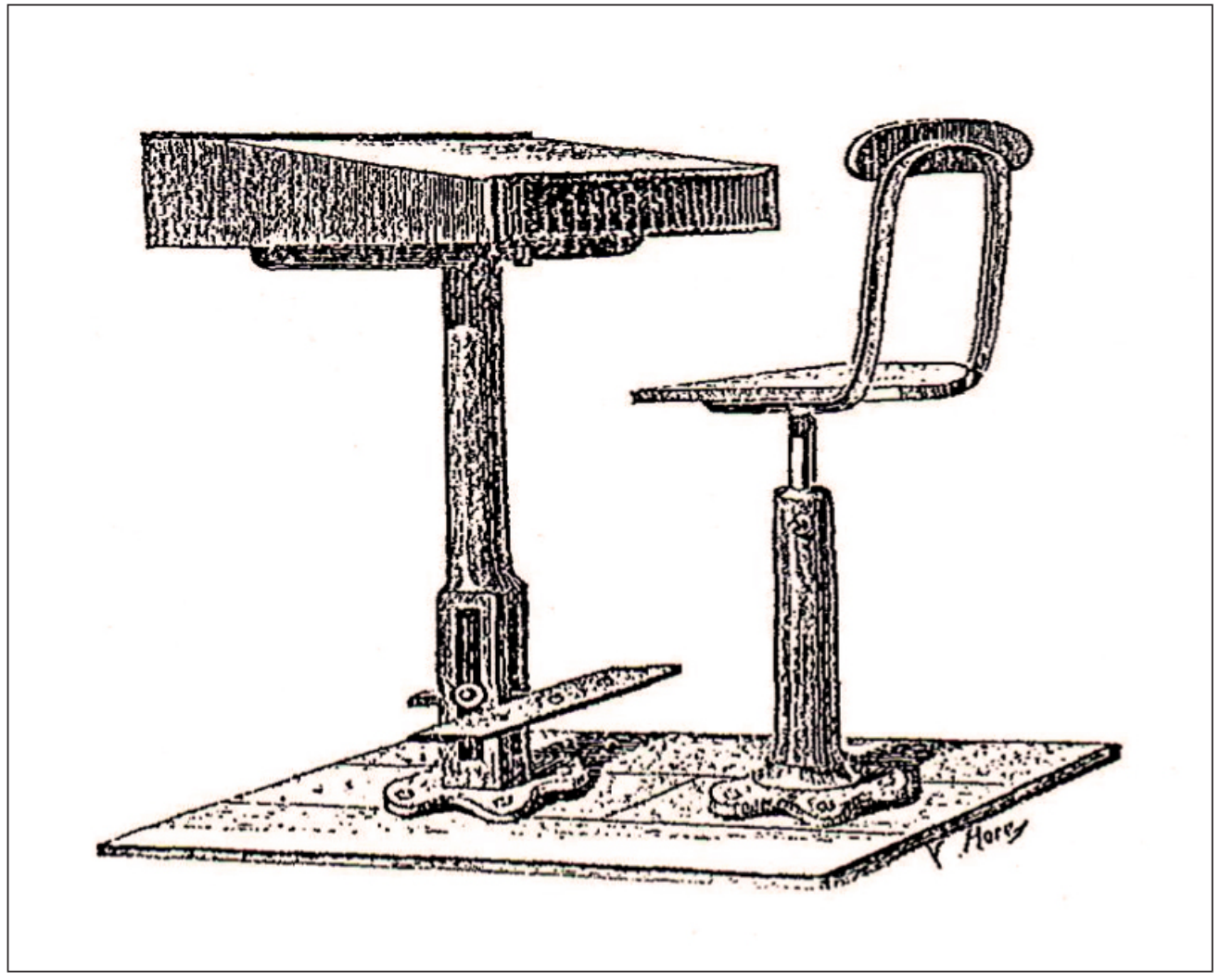

Figura 19 - Modelo de mesa-banco Bapterosses. Imagem extraída do livro de Aimé Riant (1874, p. 157).

a todos as outras, na qual o princípio é o mesmo, poderia ao contrário ser adotada utilmente nas classes onde os alunos tenham idade para ajustar eles mesmo a sua altura"152.

Por fim, também participaram da exposição dois diretores e proprietários de instituição de ensino, Menezes Vieira e o diretor do Externato Silva Ramos, cujo nome não aparece no documento e que parece não ter chamado atenção da comissão, para a qual "os moveis expostos por este estabelecimento não têm todas as condições essenciais d'uma mobilia escolar" ${ }^{\prime \prime} 13$.

Menezes Vieira destacou-se com a exibição de cinco móveis. Uma mesinha e cadeirinha para aluno do jardim da infância, "imitação do modelo Bapterosses [...] com modificações introduzidas pelo distinto diretor do Colégio" 154 . Mesa e banco para dois alunos do jardim, modelo Hachette; carteira e banco para dois alunos semelhante ao modelo Triumph dos Estados Unidos; "Mesa com tampo quadriculado para um alumno do jardim, modelo e fabrico norte-americano"; e "bancos-carteiras americanos comuns"155. A adaptação de material e mobiliário escolar era uma marca do trabalho de Menezes Vieira ${ }^{156}$.

Menezes Vieira, além da menção honrosa "pelos moveis que fez construir, segundo seu plano para os jardins da infancia"157, recebeu o diploma 
de Primeira Classe. Dentre outros produtos, ele expôs tinteiros e móveis ${ }^{158}$. A despeito de se tratar de um colégio no Rio de Janeiro, não em São Paulo, vale destacar a participação do seu proprietário e diretor, Menezes Vieira, nas exposições nacionais e internacionais. Como educador, diretor do Pedagogium e homem de negócios, ele adaptou e fez circular no Brasil material e mobiliário escolar de fabricação estrangeira e expostos nas grandes feiras universais ${ }^{159}$

\section{De acordo com Bastos, Menezes Vieira envia trabalhos}

à Exposições Universal de Buenos Aires (1882); da Antuérpia (1883); à Exposição Internacional de Higiene e Educação, realizada em Londres em 1884 [...] Na Exposição Universal de Paris em 1889, Menezes Vieira teve uma participação significativa. No catálogo oficial do Brasil na Exposição Universal, consta como membro da comissão brasileira de estudos. Na lista de delegados estrangeiros, seu nome aparece como diretor da Escola Normal do Rio de Janeiro ${ }^{160}$.
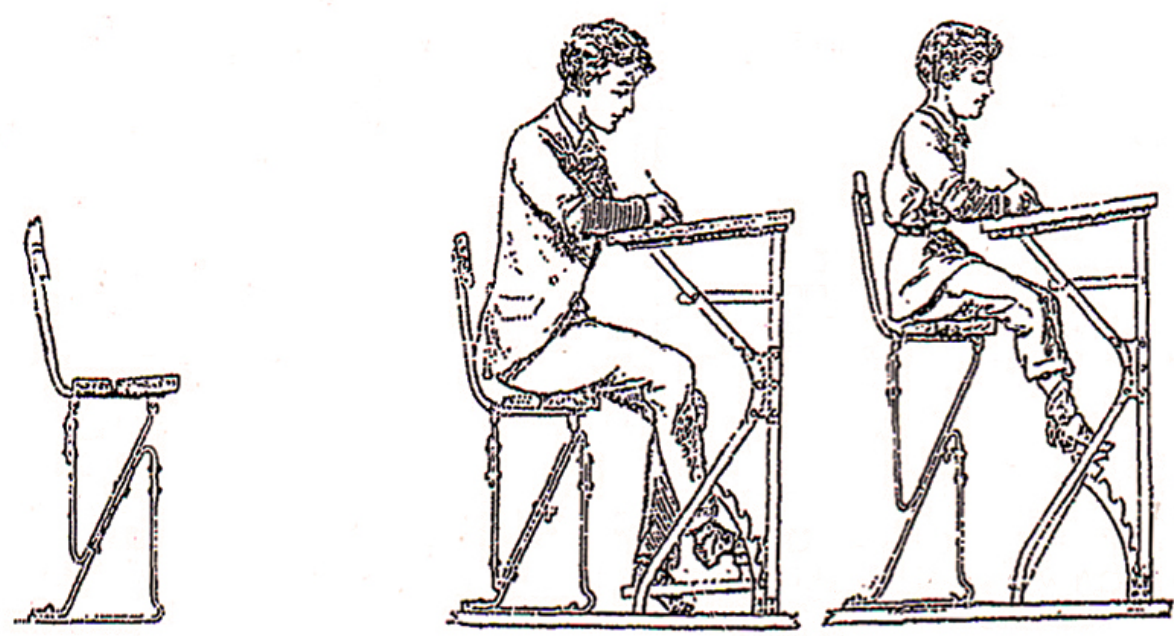

Fig 75. Modêle Andre, table-banc adaptable d̀ toutes les tailles

Figura 20 - Carteira modelo André. Publicada em Revue Pedagogique (1879, p. 132). Imagem extraída do livro de Josette Peyranne (2001, p. 165).

No Rio de Janeiro (exposição de 1883), apesar de representar um colégio brasileiro, ele "expôs relativamente à lição de coisas e à ornamentação escolar uma variedade de material estrangeiro"161.

A primeira pesquisa sobre a Exposição Pedagógica de 1883 foi feita por Therezinha Collichio. Segundo ela, a exuberância da exposição entra em conflito com "a pobreza das instituições escolares e a desorganização do sistema de ensino no período"162.
158. Ver, Maria Helena Camara Bastos (2002).

159. Sobre o assunto, ver Diana Gonçalves Vidal (2006).

160. Cf. Maria Helena Camara Bastos (2002, p. 47).

161. Cf. Maria Helena Camara Bastos (2002, p. 71).

162. Cf. Therezinha Collichio $(1987$, p. 6) 
163. Cf. Maria Helena Camara Bastos (2002, p. 153).

164. Cf. Heloisa Barbuy (1999, p. 17).

165. Cf. Heloisa Barbuy (1999, p. 17).

166. Ver Diana Vidal; Vera Gaspar (2011)
A pretensão de realizar um congresso da instrução evidencia o interesse de "integrar o Brasil na modernidade liberal, vulgarizar as modernidades educacionais e os conhecimentos, tendo por base sociedades de referência como os Estados Unidos, França, Inglaterra, Bélgica, Áustria, dentre outros"163.

É possível que a Exposição Pedagógica do Rio de Janeiro tenha tornado mais visível aquilo que só os que podiam visitar as exposições universais sabiam: fabricar e vender carteiras e objetos escolares era um negócio rentável. As exposições nacionais foram, de um lado, "veículo para instruir (ou industriar) as massas sobre os novos padrões da sociedade industrial"; e, de outro, "fórum para atividades comerciais ligadas à indústria"164.

Nem todos os professores, diretores de escola, e mesmo negociantes, poderiam ter acesso às "materializações de uma visão de mundo que se quer, conscientemente, difundir" 165 nas exposições universais. Assim, as nacionais traziam para mais perto as questões higiênicas, pedagógicas, técnicas e econômicas que subjaziam à presença dos novos e modernos objetos escolares.

A difusão nas exposições desses valores e conhecimentos acerca do novo universo material que invadiu a escola no fim do século XIX contribuiu para a proliferação de indústrias e empresas dedicadas à fabricação e à comercialização de objetos escolares.

Considerações finais

A discussão sobre os modelos de carteira apresentados nas exposições nacionais e locais sobre as patentes de tais modelos faz emergir aspectos da história da escola que ultrapassavam as fronteiras nacionais, mostrando a forte relação que se foi se estabelecendo entre escola e indústria, e escola e mercado na constituição do ensino obrigatório no fim do século XIX.

A importância conferida à criação dos sistemas de ensino e ao mobiliário escolar, na segunda metade do século XIX, se dá internacionalmente e as exposições universais são veículos significativos de propagação de uma modernidade pedagógica que se expressa nos objetos e materiais escolares. As grandes feiras universais fizeram das carteiras objetos de desejo e de necessidade para a escola moderna. Nesse caso, além de valores higiênico e comercial, há um valor cultural associado à aquisição de determinados bens. Esse valor cultural faz crer que mobiliário moderno é igual à escola moderna que é igual à qualidade de educação. Como já assinalaram Vidal e Gaspar 166, há uma retórica hegemônica do campo educacional brasileiro que associa, diretamente, qualidade de ensino e aquisição de tecnologias e modernos materiais escolares. Para essa retórica, contribuíram as exposições universais e nacionais.

Ao se tratar da transnacionalização de objetos escolares no fim do século XIX, fica em evidência que a estruturação das condições físicas de funcionamento da escola moderna, pública e obrigatória, de um lado, observava 
padrões que extrapolavam as fronteiras nacionais, e, de outro, tais padrões sofriam adaptações às realidades locais. É o que acontece com as carteiras de pé de ferro americanas. Embora tenha se tornado um modelo hegemônico em muitos países do ocidente, na Exposição Pedagógica do Rio de Janeiro de 1883, os jurados brasileiros deixam claro que os custos com manutenção tornam tal mobiliário impróprio à realidade brasileira, sobretudo, às escolas rurais.

O propósito deste artigo foi chamar a atenção para a via de mão dupla da relação entre escola, indústria e exposições universais no período de estruturação da escola moderna, pública e obrigatória. De um lado, a escola movimenta o mercado, como se observa no caso das patentes, e as necessidades dela fazem com que ele se adapte para atender as suas demandas; novos serviços se organizam, novas indústrias se desenvolvem e lucram tendo o Estado como comprador privilegiado. De outro lado, o mercado cria objetos de desejos para a escola. O Estado dele depende para produção, em grande quantidade e em curto tempo, de um mobiliário padronizado que corrobore para a expansão do ensino. 


\section{REFERÊNCIAS}

BAGCHI, Barnita; FUCHS, Eckhardt; ROUSMANIERE, Kate (orgs). Connecting Histories of Education: Transnational and Cross-Cultural Exchanges in (Post-) Colonial Education. Nova Iorque: Berghahn Books, 2014, p. 225.

BARBUY, Heloisa. A Exposição Universal de 1889 em Paris: visão e representação na sociedade industrial. São Paulo: Loyola; História Social USP, 1999.

BASSO, Maristela. O Direito Internacional da Propriedade Intelectual. Porto Alegre: Livraria do Advogado, 2000.

BASTOS, Maria Helena Camara. Pro Patria Laboremus: Joaquim José de Menezes Vieira (1848-1897). Bragança Paulista: EDUSF, 2002.

. A educação como espetáculo. In: STEPHANOU, Maria; BASTOS, Maria Helena C. (orgs). Histórias e memórias da educação no Brasil. Vol II: século XIX. Petrópolis, RJ: Vozes, 2005, p.116-131.

BUISSON, Ferdinand. Rapport sur l'instruction primaire à l'Exposição Universelle de Vienne em 1873. Paris: Imprimerie Nationale, 1875.

BUISSON, Ferdinand. Dictionnaire de Pédagogie et d'instruction primaire. Paris: Librairie Hachette et Cie., 1888. Parte I, Tomo II.

COLliCHIO, Therezinha A. F. Dois eventos importantes para a História da Educação Brasileira: a Exposição Pedagógica de 1883 e as Conferências Populares da Freguesia da Glória. Revista da Faculdade de Educação, USP, São Paulo, v. 13, n.2, p. 5-14, jul/dez. 1987.

FUCHS, Eckhardt. History of Education beyond the nation? Trends in Historical and Educational Scholarship. In: BAGCHI, Barnita; FUCHS, Eckhardt; ROUSMANIERE, Kate (orgs). Connecting Histories of Education: Transnational and Cross-Cultural Exchanges in (Post-)Colonial Education. Nova Iorque: Berghahn Books, 2014, p. 11-26.

GROSVENOR, Ian. Pleasing to the Eye and at the Same Time Useful in Purpose: a historical exploration of educational exhibitions. In: LAWN, Martin; GROSVENOR, Ian. Materialities of Schooling: Design, Technology, Objects, Routines. Oxford: Symposium Books, 2005. 
KUHLMANN JR., Moysés. As grandes festas didáticas: a educação brasileira e as exposições internacionais (1862-1922). Bragança Paulista: Editora da Universidade São Francisco, 2001.

KUHLMANN JR., Moysés. A educação infantil no século XIX. In: STEPHANOU, Maria; BASTOS, Maria Helena C (orgs). Histórias e memórias da educação no Brasil. Vol II: século XIX. Petrópolis, RJ: Vozes, 2005, p. 68-77.

LAWN, Martin. A Pedagogy for the public: the place of objects, observation, mechanical production and cupboards. In: LAWN, Martin; GROSVENOR, Ian (éd.). Materialities of Schooling: design, technology, objects, routines. Oxford: Symposium Books, 2005, p.145-162.

LAWN, Martin; GROSVENOR, Ian (org.). Materialities of Schooling: design, technology, objects, routines. Oxford: Symposium Books, 2005. (Comparative Histories of Education).

MENESES, Ulpiano T. Bezerra de. Memória e cultura material: documentos pessoais no espaço público. Estudos Históricos, Rio de Janeiro, v. 11, n.21, p. 89-104, 1998.

PEYRANNE, Josette. Le mobilier scolaire du XIXe siècle a nos jours: contribution a l'étude des pratiques corporelles et de la pédagogie à travers l'évolution du mobilier scolaire. Lille: ANRT, 2001.

REQUIÃO, Rubens. Curso de Direito Comercial. 30a ed. São Paulo: Saraiva, 2011.

SCHOROEDER-GUDEHUS, Brigitte; RASMUSSEN, Anne. Les fastes Du progrès: guide dês expositions universaelles, 1851-1992. Paris: Flammarion, 1992.

SCHRIEWER, Jürgen. L'internationalisation des discours sur l'éducation: adoption d'une "idéologie mondiale" ou persistence du style de "réflexion systémique" spécifiquement nationale? Revue Française de Pédagogie. Paris, n.146, p. 7-26, janvier-février-mars, 2004.

TRILLO, Mauricio Tenório. Artilugio de la Nación Moderna: México nas exposições universais 1880-1930. México: Editorial Fondo de Cultura Económica, 1998.

VIDAL, Diana Gonçalves. O museu escolar brasileiro: Brasil, Portugal e a França no âmbito de uma história conectada (final do século XIX). In: FERNANDES, Rogério; LOPES, Alberto; FARIA FILHO, Luciano Mendes de. (Org.). Para a compreensão histórica da infância. Porto: Campo das Letras, 2006, v. 1, p. 239-264.

VIDAL, Diana Gonçalves; GASPAR, Vera. Por uma história sensorial da escola e da escolarização. In: CASTRO, Cesar Augusto de. (Org.). Cultura material escolar: a escola e seus artefatos (MA, SP, PR, SC e RS, 1870-1925). São Luís: Café \& Lápis, 2011, v. 1, p. 19-42. 


\section{FONTES}

BROOKE, J.C. Catalogue church school and hall furniture. Cincinatio: The Firm, 1884.

DE BAGNAUX. Le mobilier scolaire. Revue Pedagogique. Paris, 1879.

GEO \& C. W. SHERWOOD. A descriptive and illustrated catalogue of school furniture. Chicago: Tribune company's printing establishment, 1864.

J.A.BANCROFT \& CO. Descriptive and Illustrated Catalogue of School Merchandise, Furniture, apparatus, Charts, \& C. Philadelphia: The Company, 1870.

RIANT, A. Hygiène Scolaire: Influence de l'École sur la santé des enfants. Paris: Librairie Hachette \& Cie, 1874.

ROSS, JOSEPH L. Illustrated Catalogue of Improved School, Church, and Vestry Furniture. Boston: Hollis \& Gunn, Book and Job Printers, 1872.

STERLING SCHOOL FURNITURE CO. Price list of school furniture. Albany/New York, 1875.

THE NATIONAL SCHOOL FURNITURE C ${ }^{\circ}$. Illustrated Catalogue of New and Improved Styles of School and Church Furniture and School Apparatus. New York/Chicago, 1872.

UNION SCHOOL FURNITURE COMPANY. Descriptive catalogue of school furniture and supplies. Michigan: Factory and Office, Battle Creek, 1889.

\section{Instituto Histórico e Geográfico Brasileiro}

BREWER, Eben. Vienna Universal Exhibition de 1873. Official catalogue of the American Department. Nova Iorque: J. M. Johnson \& Sons, 1873, p.99-114.

RIO DE JANEIRO. Primeira Exposição Pedagógica do Rio de Janeiro. Typographia Nacional, 1884. Relatório do Jury. Grupo 3. p. 23-46.

RIO DE JANEIRO. Exposição Pedagógica, 1883. Conferências effectuadas na exposição pedagógica. Rio de Janeiro: Imprensa Nacional, 1884. 


\section{Bibliotèque Nationale de France}

DELAGRAVE. Catalogue spécial de mobilier et materiel scolaire et acessoires de classes. Paris: Librairie Delagrave. Deuxieme partie, 1890. Disponível em: gallica.bnf.fr / Bibliothèque Nationale de France. Acesso em: 26 de fevereiro de 2013.

EXPOSITION DE 1878. Le Mobilier Scolaire à l'Exposition Internationale de 1878. Disponível em: gallica.bnf.fr / Bibliothèque Nationale de France. Acesso em: 27 de fevereiro de 2013.

GARCET, P.; NISIUS. Mobilier Scolaire et Matériel d'Enseignement. Catalogue. Paris: Usine a Faucogney et a la Coorveraine, 1882.

\section{Biblioteca Nacional Digital Brasil}

ALMANAK ADMINISTRATIVO, Mercantil e Industrial do Rio de Janeiro, do ano de 1898 e indicador para o ano de 1898. Rio de Janeiro: Companhia Typographica do Brazil. Disponível em: http://hemerotecadigital.bn.br/acervo-digital/almanak-administrativo-mercantil-industrialrio-janeiro/313394. Acesso em: 20 de set. 2013.

Artigo apresentado em 16/05/2016. Aprovado em 09/08/2016. 
